Nat. Hazards Earth Syst. Sci., 18, 2161-2181, 2018

https://doi.org/10.5194/nhess-18-2161-2018

(c) Author(s) 2018. This work is distributed under

the Creative Commons Attribution 4.0 License.

\title{
Global fatal landslide occurrence from 2004 to 2016
}

\author{
Melanie J. Froude and David N. Petley \\ Department of Geography, University of Sheffield, Sheffield, S10 2TN, UK
}

Correspondence: Melanie J. Froude (m.froude@ sheffield.ac.uk)

Received: 23 February 2018 - Discussion started: 1 March 2018

Revised: 12 June 2018 - Accepted: 22 June 2018 - Published: 23 August 2018

\begin{abstract}
Landslides are a ubiquitous hazard in terrestrial environments with slopes, incurring human fatalities in urban settlements, along transport corridors and at sites of rural industry. Assessment of landslide risk requires high-quality landslide databases. Recently, global landslide databases have shown the extent to which landslides impact on society and identified areas most at risk. Previous global analysis has focused on rainfall-triggered landslides over short $\sim 5$ year observation periods. This paper presents spatiotemporal analysis of a global dataset of fatal non-seismic landslides, covering the period from January 2004 to December 2016. The data show that in total 55997 people were killed in 4862 distinct landslide events. The spatial distribution of landslides is heterogeneous, with Asia representing the dominant geographical area. There are high levels of interannual variation in the occurrence of landslides. Although more active years coincide with recognised patterns of regional rainfall driven by climate anomalies, climate modes (such as El Niño-Southern Oscillation) cannot yet be related to landsliding, requiring a landslide dataset of $30+$ years. Our analysis demonstrates that landslide occurrence triggered by human activity is increasing, in particular in relation to construction, illegal mining and hill cutting. This supports notions that human disturbance may be more detrimental to future landslide incidence than climate.
\end{abstract}

\section{Introduction}

Landslides are ubiquitous in any terrestrial environment with slopes, driven by tectonic (e.g. Bennett et al., 2016), climatic (e.g. Moreiras, 2005) and/or human (Petley et al., 2007) activities. Losses (fatalities, physical asset damage and economic costs) occur when people and their associated structures are exposed to landslides. The magnitude of the im- pact depends on the number of exposed elements and their associated vulnerabilities, the consequences of the impacts and the intensity of the landslide event (Glade and Crozier, 2005). A landslide event may include more than one slope failure triggered by the same phenomenon (e.g. a rainstorm). Interest in quantifying landslide risk has developed since the attempt by the International Association of Engineering Geology (IAEG) Commission on Landslides to compile a list of worldwide landslide events for the UNESCO annual summary of information on natural disasters in 1971 (UNESCO, 1973). Although incomplete, 5 years of records (1971-1975) recognised that landslides are a significant global hazard, with ca. $14 \%$ of total casualties from natural hazards being attributed to slope failure (Varnes and IAEG Commission on Landslides, 1984). Since then, there has been a growing interest in landslide hazard and risk assessment (Wu et al., 2015).

Key elements of the assessment of landslide risk are coherent, high-quality landslide databases and inventories (van Westen et al., 2008; Van Den Eeckhaut and Hervás, 2012; Taylor et al., 2015). Inventories provide systematically compiled lists of landslide events that have occurred over a specific spatial scale (e.g. within a nation) within a set period of time or that result from a single, catastrophic triggering event (Hervás and Bobrowsky, 2009). Databases organise inventory information so that it is structured and searchable. Spatiotemporal analysis of global records of landslides have demonstrated the extent to which landslides impact on society and have identified geographical regions and countries most exposed (Petley, 2012). Several different global databases are actively maintained (e.g. the EM-DAT International Disaster Database, the NASA Global Landslide Catalogue and the Global Fatal Landslide Database (GFLD) on which this study is based), and their merits and limitations are discussed by Van Den Eeckhaut and Hervás (2012) and 
Kirschbaum et al. (2015). Global disaster databases are also maintained by risk reinsurers, but landslides are often included within broader categories (such as geophysical hazards or within weather-related hazards), and the majority of data are not freely available.

Relative to other natural disasters, the International Disaster Database (EM-DAT) suggests that landslides account for $4.9 \%$ of all natural disaster events and $1.3 \%$ of all natural hazard fatalities between 1990 and 2015; $54 \%$ of these landslide events occurred in Asia (Guha-Sapir et al., 2018). However, the dedicated global landslide databases indicate that global multi-peril databases underestimate the impact of landslides on society. Petley (2012) showed that the EMDAT database underestimated the number of fatal landslide events by $\sim 2000 \%$ and fatalities by $430 \%$ between 2004 and 2010, whilst Kirschbaum et al. (2015) showed that the EM-DAT database underestimated the number of fatal landslide events by $\sim 1400 \%$ and fatalities by $331 \%$ between 2007 and 2013. For the most part this under-reporting is associated with the perception of landslides as a secondary hazard, with the cause of death often being recorded in connection with the primary hazard (e.g. an earthquake rather than a coseismic landslide) rather than the actual cause of the loss.

Past studies on global landslide distribution have focused on rainfall-triggered events, recognising the importance of rainfall and climate in inhabited regions with steep slopes (Dowling and Santi, 2014; Kirschbaum et al., 2012, 2015). This paper not only provides a key update on the impact of landslides worldwide, extending Petley (2012) to include landslides from 2004 to 2016, the study also considers trends in landslides triggered by human activity, thereby adding to the discussion on climate versus human disturbance as current and future drivers of landslide incidence (Crozier, 2010).

\section{The Global Fatal Landslide Database}

The GFLD (formerly termed the Durham Fatal Landslide Database) has been compiled using systematic metadata search tools based in the English language that identify relevant reports of landslide activity (including all mass movements falling within the definition of Hungr et al., 2014) on a daily basis (Petley et al., 2005; Petley, 2010, 2012). In common with other hazard databases (Tschoegl et al., 2006; Taylor et al., 2015), mass media reports provide a first alert for fatal landslide occurrence and impact. Reports are corroborated and data updated by source triangulation using government and aid agency reports, academic papers and personal communications, as new information becomes available. The dataset has been consistently collected and managed since 2004, following a period of methodological development between 1 September 2002 and 31 December 2003 (Petley, 2012). The approach is differentiated from that of Kirschbaum et al. $(2010,2012,2015)$ because (1) only landslides that cause loss of life are included and (2) all land- slides are included, as opposed to only those triggered by rainfall. In addition, the GFLD has been compiled over a longer period. Although media reporting tends to be biased towards landslides with human casualties (Carrara et al., 2003), which is favourable for a database of this nature, it is recognised that the data collected are to some degree an underestimate of the number of fatal landslides and their associated losses. Landslides that occur in remote mountain regions, or that result in a small number of fatalities, are less likely to be reported than multi-fatality landslides and/or those that occur in urban centres (Petley, 2009). Reliability of reporting is also spatially variable, based on the robustness of regional communication networks, which are considered more consistent in developed nations (Petley, 2010; Kirschbaum et al., 2010), and in some cases political considerations (e.g. very few landslides are recorded in North Korea). The true number of fatalities may be slightly underestimated when victims die of landslide-derived injuries weeks to months following the event (Petley, 2012). Furthermore, solely non-English reporting of landslides will account for some missed reporting. Sepúlveda and Petley (2015) compared the GFLD with an independently compiled database based on original Spanish and Portuguese language reports for Latin America and found a difference of only $5 \%$ of total records, generally associated with landslides with small numbers of fatalities. Combined, these effects may underestimate the true level of loss by up to $15 \%$ (Petley, 2012); however, the methodology of collation of the GFLD is considered robust.

Since 2004, the database has been compiled to include the date of occurrence; the description of landslide location; an approximate latitude and longitude for that location; the country and geographical region (based on UN classifications, UNSD, 2018) in which the landslide occurred; the number of fatalities and injuries; and whether the event was triggered by rainfall, seismicity or another cause. Seismically triggered landslides in the database are excluded from analysis herein, because the catalogue of events is not considered complete (see Petley, 2012). These equate to 168 earthquake events and 3978 fatalities. In preparation of this paper, all landslide reports were reviewed to enhance the classification of the trigger event according to Table 1, using keyword searches in the original text describing the landslide. The description of the landslide event location may be specific to a section of road or village or give a more general location within an administrative division (such as a county or state). The locations of all landslide events are known within political country boundaries. To estimate the spatial precision of each landslide report, location descriptions were related to spatial databases of administrative boundaries (GADM, 2017), transport network maps (Google Maps, 2018; Open Street Map, 2018) and in some cases individual landslides could be identified from satellite imagery (Google Earth, 2018; Planet Team, 2017). For administrative units such as villages or states, polygon area from GADM (2017) 
Table 1. Landslide trigger classification.

\begin{tabular}{|c|c|c|}
\hline Classification & Definition & Keyword search terms \\
\hline Unknown & No trigger or obvious cause specified. & - \\
\hline Rainfall & Rainfall raises pore pressure in slope materials triggering failure. & $\begin{array}{l}\text { "rain", "sleet", "storm", "hurricane", } \\
\text { "precipitation", "flood", "water", "tor- } \\
\text { rent" }\end{array}$ \\
\hline Earthquake & $\begin{array}{l}\text { Strong ground motion associated with an earthquake weakens slope ma- } \\
\text { terials triggering failure (coseismic landslides). }\end{array}$ & $\begin{array}{l}\text { "earthquake", "aftershock", "seismic", } \\
\text { "tremor" }\end{array}$ \\
\hline Illegal mining & $\begin{array}{l}\text { Unregulated or informal mining of slope materials in designated quarry } \\
\text { or mine, where permission to extract material has not been granted. }\end{array}$ & 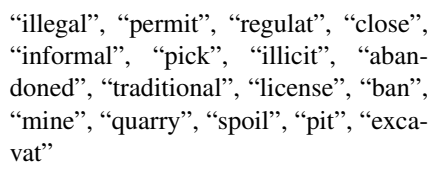 \\
\hline Illegal hill cutting & $\begin{array}{l}\text { Hill cutting refers to the process of removing material from a hillslope } \\
\text { for the purposes of altering its shape and/or to obtain slope material for } \\
\text { use in construction, manufacture or farming. It is differentiated from } \\
\text { mining because it occurs on slopes that are not within a designated site } \\
\text { of mining or quarrying; instead hill cutting typically occurs on indi- } \\
\text { vidual slopes on steep agricultural land or on man-made slopes such } \\
\text { as those along transport routes. Hill cutting differs from construction } \\
\text { because slope modification does not follow an engineering design to } \\
\text { ensure slope stability. Hill cutting is assumed to be undertaken in an } \\
\text { informal, unregulated manner (this is frequently noted in landslide re- } \\
\text { ports). }\end{array}$ & $\begin{array}{l}\text { "hillcut", "illegal", "permit", "regulat", } \\
\text { "informal", "illicit", "traditional", "li- } \\
\text { cense", "ban", "excavat" }\end{array}$ \\
\hline Legal mining & $\begin{array}{l}\text { Regulated and/or permitted mining of slope materials in designated } \\
\text { quarry or mine, where permission to extract material has been granted } \\
\text { and operations are managed. }\end{array}$ & $\begin{array}{l}\text { "legal", "permit", “regulat", "pick", } \\
\text { "license", "mine”, "quarry", "spoil”, } \\
\text { "pit", "excavat" }\end{array}$ \\
\hline Mining (unknown) & $\begin{array}{l}\text { Slope materials are extracted from a designated quarry or mine, but the } \\
\text { report does not make it clear whether the extraction is permitted or not. }\end{array}$ & $\begin{array}{l}\text { "quarry", "mine", "spoil", "pit", "exca- } \\
\text { vat" }\end{array}$ \\
\hline Construction & $\begin{array}{l}\text { Permitted modification of a slope for the purposes of a construction } \\
\text { project undertaken by professional labourers, following planning ap- } \\
\text { proval. }\end{array}$ & $\begin{array}{l}\text { "excavat", "construction", "site", } \\
\text { "road", "build", "dig", "labour" }\end{array}$ \\
\hline Conflict and explosion & $\begin{array}{l}\text { Landslide triggered by the detonation of an explosive device during mil- } \\
\text { itary combat. }\end{array}$ & $\begin{array}{l}\text { "bomb", "mine", "soldier", "army", } \\
\text { "explode", "explosion", "war", "con- } \\
\text { flict" }\end{array}$ \\
\hline Leaking pipe & $\begin{array}{l}\text { Utility pipes carrying water have been damaged and leak water onto a } \\
\text { slope surface or within the hillslope, compromising its stability. }\end{array}$ & "pipe", "leak", "burst" \\
\hline Garbage collapse & $\begin{array}{l}\text { Collapse of piles of municipal waste onto people, where stability of } \\
\text { waste piles was disturbed by the passage of a person or persons. }\end{array}$ & $\begin{array}{l}\text { "waste", "trash", "rubbish", "garbage”, } \\
\text { "dump", "pick" }\end{array}$ \\
\hline Recreation & $\begin{array}{l}\text { Triggered by passage of a person or persons walking or climbing over a } \\
\text { hillslope for recreation. }\end{array}$ & $\begin{array}{l}\text { "climb", "mountain", "expedition", } \\
\text { "ascent", "trek" }\end{array}$ \\
\hline Human action (unspecified) & $\begin{array}{l}\text { Landslide report refers to a person or people present on a hillslope that } \\
\text { collapses, without specifying the reason people occupied the slope or } \\
\text { the landslide trigger. }\end{array}$ & $\begin{array}{l}\text { "people”, "person", "men”, "women”, } \\
\text { "children", "occup" }\end{array}$ \\
\hline Animal activity & $\begin{array}{l}\text { Occupation of slope by animal triggering failure, either by weight and } \\
\text { movement of animal on slope surface or by burrowing within the slope } \\
\text { subsurface. }\end{array}$ & "animal”, "burrow", “tunnel” \\
\hline Fire & $\begin{array}{l}\text { Naturally occurring or man-made fires, typically occurring in dry cli- } \\
\text { mates on vegetated terrain. }\end{array}$ & "fire" \\
\hline Natural dam or riverbank collapse & $\begin{array}{l}\text { Collapse of a riverbank or natural dam without an apparent trigger, but } \\
\text { likely caused by pore pressures building over time to a critical threshold } \\
\text { in response to water levels. Material typically fails into a body of water } \\
\text { and often generates a flood wave. }\end{array}$ & $\begin{array}{l}\text { "river", "bank", "dam", "earth", } \\
\text { "flood", "wave", "collapse" }\end{array}$ \\
\hline Freezing & $\begin{array}{l}\text { Heavy snowfall and expansion of water in hillslopes due to freezing, } \\
\text { acting solely or together to destabilise the slope. }\end{array}$ & $\begin{array}{l}\text { "snow", "extreme", "freeze", "ice", } \\
\text { "cold" }\end{array}$ \\
\hline $\begin{array}{l}\text { Freeze-thaw (temperature change cold } \\
\text { to hot), snowmelt }\end{array}$ & $\begin{array}{l}\text { Failure of slope materials in response to temperature rise, including } \\
\text { landslides triggered by the melting of snow or permafrost (in a non- } \\
\text { volcanic setting). }\end{array}$ & $\begin{array}{l}\text { "snow", "melt", "permafrost", } \\
\text { "spring", "temperature", }\end{array}$ \\
\hline Volcanic eruption & $\begin{array}{l}\text { Landslides (and mudflows) occurring in a volcanic environment trig- } \\
\text { gered by volcanic activity such as explosions and volcano-tectonic seis- } \\
\text { micity. This does not include events in active volcanic environments } \\
\text { triggered by rainfall. }\end{array}$ & $\begin{array}{l}\text { "volcan", "seismic", "activity", "erup- } \\
\text { tion" }\end{array}$ \\
\hline Marine erosion & Triggered by sea erosion (only) repeat wave impact. & "coast", "sea", "erode" \\
\hline
\end{tabular}


provided the measurement of spatial precision. For a stretch of road, a polyline of the road length was created using transport network data (Open Street Map, 2018) and a $500 \mathrm{~m}$ buffer applied; the area of the buffer provided the precision estimate. The median spatial precision of entries is $681 \mathrm{~km}^{2}$, with an interquartile range of 1 to $3477 \mathrm{~km}^{2}$. The data are available to view at ESRI ArcGIS online at https://shefuni.maps.arcgis.com/apps/webappviewer/index. html?id=98462998953c4f1fbd7caaa166373f63 (Froude and Petley, 2018).

\section{Global fatal landslide occurrence, 2004 to 2016}

The total number of fatal landslide events recorded worldwide, excluding those triggered by earthquakes, over the 12 calendar years between 2004 and 2016 (inclusive) was 4862 . The majority of events (95\%) involved a single slope failure. The spatial distribution of landslides (Fig. 1a and c) is clearly heterogeneous, with high areas of incidence in

- Central America between Costa Rica and the South of Mexico;

- the Caribbean islands;

- South America, along the Andes mountain range from Venezuela to Bolivia and to a lesser extent Chile, with another cluster of events on the east coast of Brazil around the states of São Paolo and Rio de Janeiro;

- East Africa, around the borders between Tanzania, Rwanda, Burundi, Kenya, Uganda and Democratic Republic of the Congo;

- Asia (the site of the highest number of events; $75 \%$ of landslides), with substantial numbers of landslides along the Himalayan Arc, in states across India and southeastern China, in the neighbouring countries of Laos, Bangladesh and Myanmar, and southwards on islands that form Indonesia and the Philippines;

- Turkey, Iran and the European Alps.

Fatal landslide events cluster around cities (Fig. 1c) and occur most frequently in countries with lower gross national income (GNI in Fig. 1c) at locations known to be susceptible to landslides, based on the analysis of physical characteristics of the environment (see Hong et al., 2007; Stanley and Kirschbaum, 2017). Textual analysis of landslide reports shows many events occurred in mines or quarries (423 landslides), and 568 landslides in the dataset occurred on roads. Relative poverty is also emphasised in reporting: the term "slum" is explicitly used to describe the impacted community 29 times, while broader terms to indicate relative poverty are used 267 times within landslide reports.
These observations support previous research that fatal landslides are most prevalent in densely occupied urban centres (Alexander, 1989; Anderson, 1992; Petley, 2009), along roads (Hearn, 2011; Lee et al., 2018) and at sites rich in natural resources (Zou et al., 2018). In common with other natural hazards, the poor are disproportionately affected by landslides (Hallegatte et al., 2016).

Figure 2 shows landslide occurrence in pentads, smoothed with a 25-day (i.e. five pentad) moving average. The most landslide events in a single pentad was 48, in early October 2009; of these 45 were triggered in a single day (8 October 2009) by Typhoon Parma in the Philippines. Rainfall is the leading trigger of landslides. The majority of nonseismic fatal landslide events (2004-2016) in the database were triggered by rainfall $(79 \%)$. Figure 3 a shows landslide events triggered by rainfall in pentads, compared with the complete non-seismic landslide event dataset. The data series are strongly correlated ( $R$ of $0.933, p$ value of 0 ), indicating that rainfall-triggered landslides explain $93 \%$ of the variance of the complete dataset. Figure $3 \mathrm{~b}$ shows landslide events that were not triggered by rainfall and where the trigger is known (e.g. mining). We term these events "nonseismic non-rainfall triggered" (NSNR) landslides herein. These landslide events constitute $16 \%$ of the complete dataset and present a different pattern through time when compared with rainfall-triggered landslide events. There is a notable increase in the number of landslide events with NSNR triggers from about 2006, which we ascribe to improved event capture.

The rainfall-triggered landslide data in Fig. 3a (and the complete landslide series in Fig. 2) contain a strong seasonal pattern of landslide occurrence through the annual cycle, as noted by Petley (2012). Autocorrelation measures the linear relationship between lagged values of a time series. The autocorrelation of the rainfall-triggered pentad landslides series (Supplement Fig. S1) shows the correlation coefficient between the original series and a lagged version of the series, where the series lags between 1 and 948 pentads ( 5 days to $\sim 13$ years). The autocorrelation oscillates around 73.5 lags (pentads), equating to 1 calendar year. This pattern is indicative of annual seasonality in the data. Conversely, the autocorrelation of the NSNR landslides pentad series (Fig. S2) does not contain this pattern and the correlation coefficients are generally weak. This indicates that there is no seasonal pattern in the NSNR landslide series, which is to be expected in events that are not triggered by meteorological processes.

\subsection{Seasonality}

Landslide event occurrence peaks in the northern hemispheric summer, and there is notable interannual variation, in both the size and shape of the annual cycle. Seasonality in the global series (Figs. 2 and 3a) is associated with the annual cycle of rainfall-triggered landslides in South, Southeast and East Asia, and South and Central America (Fig. 4). Com- 

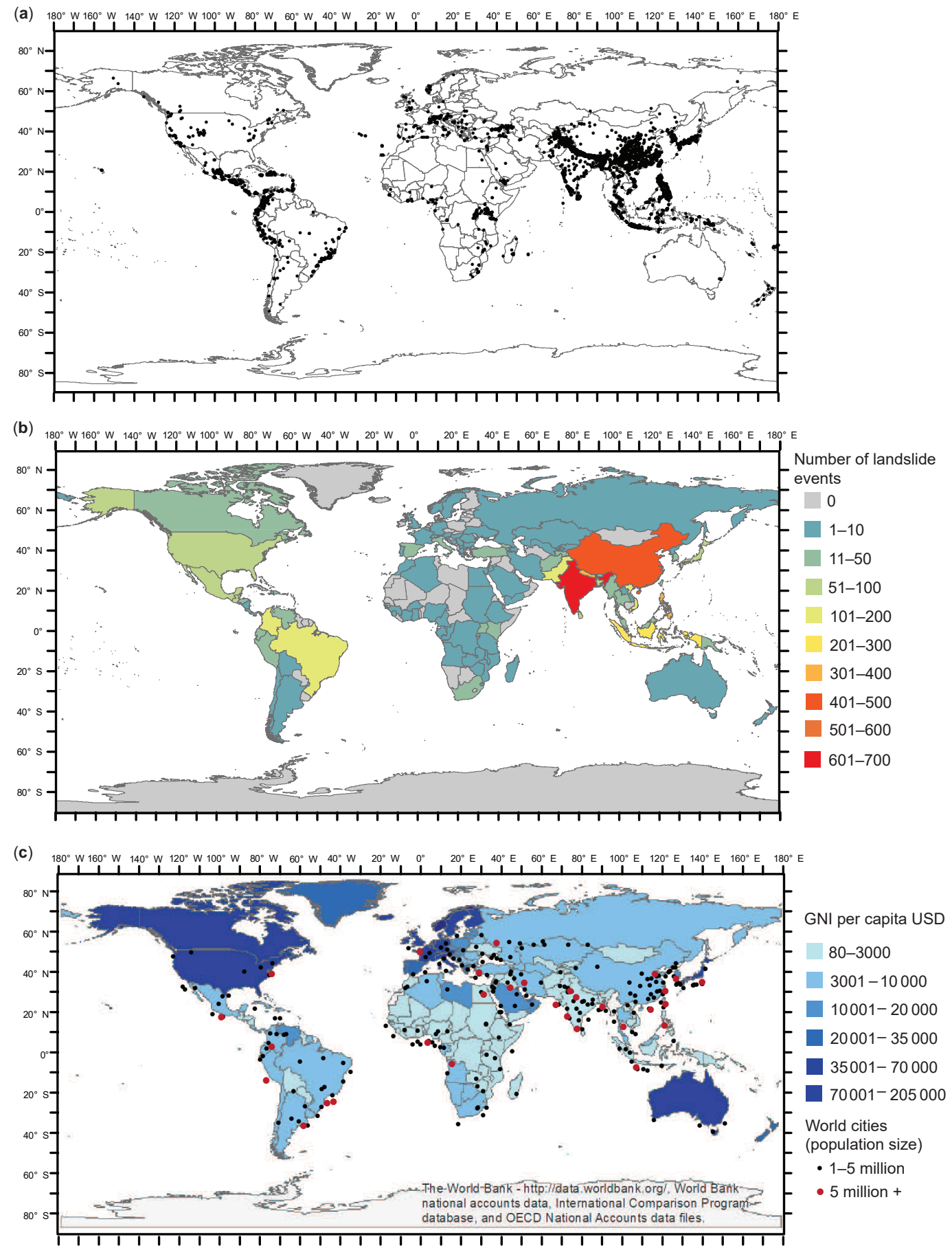

Figure 1. (a) The location of non-seismically triggered fatal landslide events from 2004 to 2016. Individual landslide events shown by a black dot. (b) Number of non-seismically triggered fatal landslide events from 2004 to 2016 by country. (c) The gross national income per capita (USD) by country (World Bank, 2018a), and the location of major urban centres globally (ESRI, 2018).

bined, these geographical regions contain $88 \%$ of all rainfalltriggered landslide events and account for $96 \%$ of variance in the global seasonal cycle (Table B1 in the Appendix). There is a correlation between the mean monthly rainfall (data from GPCC, 2018; Xie et al., 2013) and landslide series, for four of five regions (Fig. 5 and Table 2), reflecting the triggering effect of seasonal rainfall. However, the strength of relationship between seasonal patterns of rainfall and the seasonal pattern of landslide events is variable between regions. The pattern is strongest in East Asia and South Asia. This corrob- 


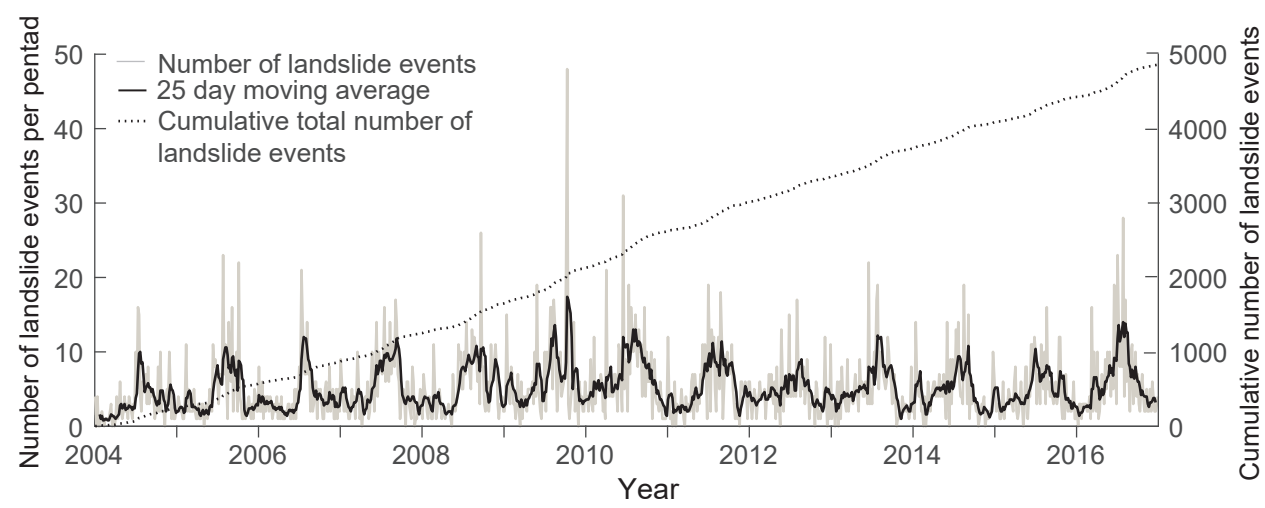

Figure 2. The occurrence of non-seismically triggered landslide events from 2004 to 2016, and cumulative total of recorded events. The data are arranged by pentads (5-day bins), starting on 1 January each year; thus the first pentad includes records for 1-5 January, and there are a total 73 pentads. A simple 25-day moving average is shown.

(a)

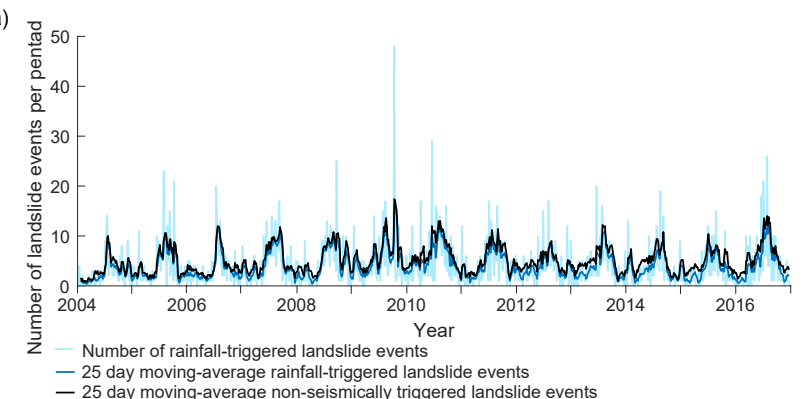

(b)

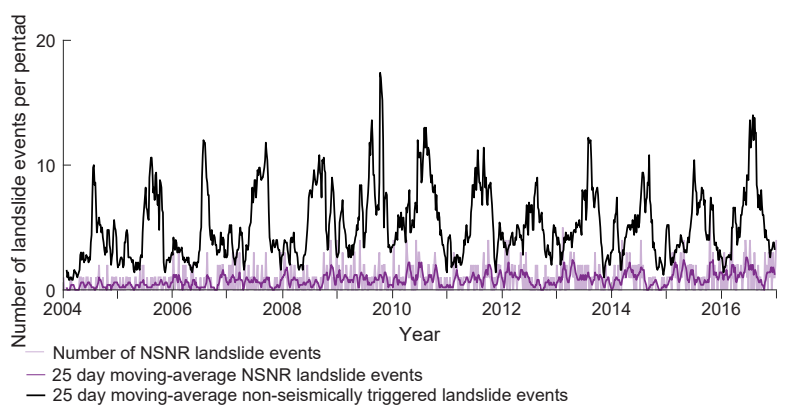

Figure 3. (a) The occurrence of rainfall-triggered landslide events from 2004 to 2016 (blue). The data are arranged by pentads (5-day bins), starting on 1 January each year. A simple 25-day moving average is shown. The 25-day moving average for all non-seismically triggered landslide events is shown in black. (b) The occurrence of NSNR landslide events from 2004 to 2016 (purple). The data are arranged by pentads (5-day bins), starting on 1 January each year. A simple 25-day moving average is shown. The 25-day moving average for all non-seismically triggered landslide events is shown in black.

orates the results of Petley (2012), who identified the strong relationship between landslide occurrence and seasonal rainfall from a shorter period of data (2004 to 2009).

Seasonal rainfall in East and South Asia is associated with the onset and withdrawal of the Asian monsoon (e.g. Web-
Table 2. Spearman's rank correlation between mean daily rainfall and mean daily landslides by month (see Fig. 5).

\begin{tabular}{lrr}
\hline Region & $\begin{array}{r}\text { Correlation } \\
\text { coefficient }\end{array}$ & $P$ value \\
\hline Central America & 0.8153 & 0.0012 \\
South America & 0.8062 & 0.0015 \\
Southeast Asia & 0.17 & 0.5974 \\
South Asia & 0.996 & 0 \\
East Asia & 0.9701 & 0 \\
\hline
\end{tabular}

ster, et al., 1998), delivered by the seasonal reversing of winds to flow from ocean to land in the summer months, resulting in the majority of annual rainfall occurring between June and September (Turner and Annamalai, 2012). In South Asia, landslide incidence increases in Nepal, India, Bangladesh, Bhutan and northern Pakistan during the summer monsoon. India and Nepal contribute 16 and $10 \%$ respectively of all rainfall-triggered landslide events in the global dataset; of these 77 and $93 \%$ occurred during the summer monsoon, meaning $21 \%$ of all rainfall-triggered landslide events globally were triggered by seasonal monsoon rainfall in India and Nepal. In East Asia, tropical cyclones extend the length of the rainfall season: 109 landslide events were triggered by typhoons between April and October in China, Japan and South Korea, representing $16 \%$ of rainfalltriggered landslide events in East Asia and 3\% of global rainfall-triggered landslide events. The East Asia landslide record is dominated by events in China (81\%, 503 landslides), of which 409 landslide events were triggered during the summer monsoon rainfall season. China alone contributes $15 \%$ of all global rainfall-triggered landslide events, although the pattern is heterogeneous.

Although the seasonal landslide series for Central and South America do not explain much variance in the global 


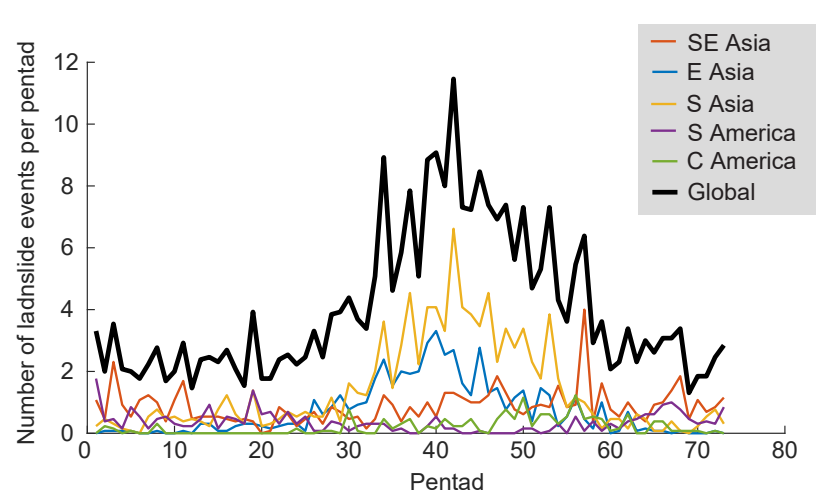

Figure 4. Mean number of landslides per pentad through the annual cycle for all rainfall-triggered landslides, by geographical region. The 20th pentad is the 6-10 April, the 40th pentad is 15-19 July and the 60th pentad is $23-27$ October.

seasonal landslide cycle (because of the comparatively low number of landslides), there is strong correlation between patterns of landslides in the region and patterns of rainfall (Table 2). Central America and parts of the Caribbean experience a summer rainy season between May and October, associated with the position of the Intertropical Convergence Zone (ITCZ; Garcia et al., 2009). The season is bimodal, with peaks in rainfall on either side of a midsummer drought between late June and August (Magaña et al., 1999). The season is enhanced by the Atlantic basin hurricane season from 1 June to 30 November (NOAA, 2018a). The pattern of landslides reflects these rainfall drivers.

South America spans $\sim 70^{\circ}$ of latitude leading to local variability in climate (Sepúlveda and Petley, 2015). The peak annual rainfall for the continent as a whole occurs during the period from December through February, delivered by the South American Monsoon System, which is driven by the position of the ITCZ to the south of the Equator (Garcia et al., 2009). However, in parts of southeastern Brazil, where there is a prevalence for fatal landslides (Fig. 1), the rainy season extends into March (Rao and Hada, 1990). In northern Peru, rainfall peaks between April and June in the west and is bimodal in the east, with peaks in April and December (Espinoza Villar et al., 2009). Colombia's meteorology is particularly complex due to the convergence of the Equatorial Mid-tropospheric Easterly Jet and the Choco Jet; the resulting rainfall distribution is bimodal, with peaks in AprilJune and August-September, depending on precise location and the choice of rainfall data and model (Sierra et al., 2015). Most rainfall-triggered fatal landslide events in South America occur in Brazil (37\%) and Colombia (32\%), most notably in southeastern Brazil and central Colombia, and this is evident in the distribution of annual rainfall and landslide occurrence (Fig. 5d).

The weak relationship between rainfall and landslides in Southeast Asia reflects the complex weather systems oper-
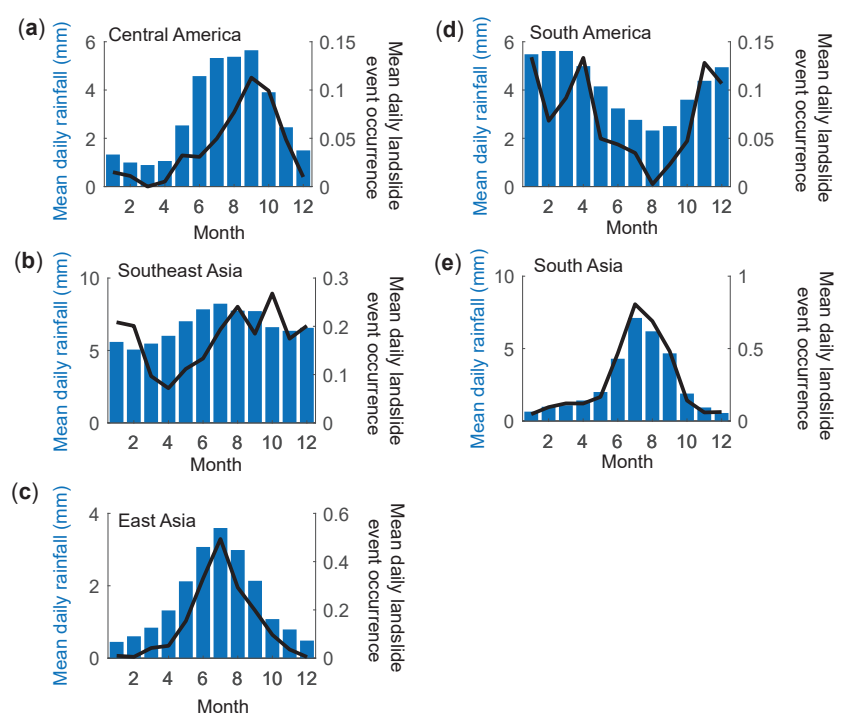

Figure 5. Mean daily rainfall (in millimetres) by month between 2004 and 2016, summarised by geographical subregion (blue bars). Global Precipitation Climatology Centre data (Xie et al., 2013; GPCC, 2018) were processed in ESRI ArcMap and MATLAB. Mean daily rainfall-triggered landslide event occurrence by month between 2004 and 2016 (black line). Daily values are used to overcome the difference in month length.

ating in the region. Most landslide events occurred in the Philippines $(46 \%)$ and Indonesia (32\%). Typhoons caused $22 \%$ of rainfall-triggered landslide events in the region, and $5 \%$ globally; most typhoon-triggered landslide events occurred in July through October (75\%), in line with the main tropical cyclone season. In the Philippines, $42 \%$ of rainfalltriggered landslide events were caused by typhoons, whilst the equivalent value for Vietnam was $22 \%$, although of a much lower total. The pattern of monsoon rainfall in Indonesia and the Philippines varies by geographical location. In the west of the Philippines, summer monsoon occurs between June and October, while in the east the winter monsoon occurs between October and March (Kubota et al., 2017). This pattern is evident in the distribution of rainfall-triggered landslides in the Philippines (Fig. 1a). The onset and termination of the monsoon in Indonesia varies from September to June in northern Sumatra and late November to late May in eastern Java (Naylor et al., 2007). Consequently, $72 \%$ of rainfall-triggered landslide events occur between November and April, when the majority of Indonesia is experiencing monsoon rainfall. The peak in landslide activity relative to rainfall in August to October in Southeast Asia (Fig. 5b) is mainly due to the localised typhoon rainfall not captured in the regional rainfall average. 
(a)

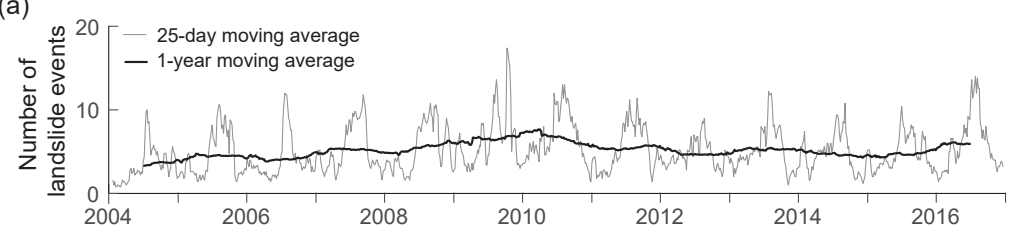

(b)

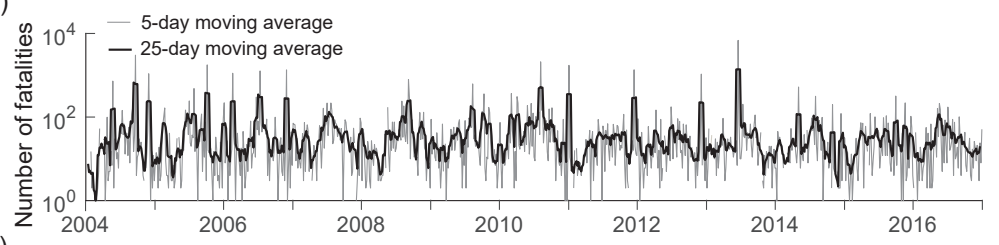

(c)

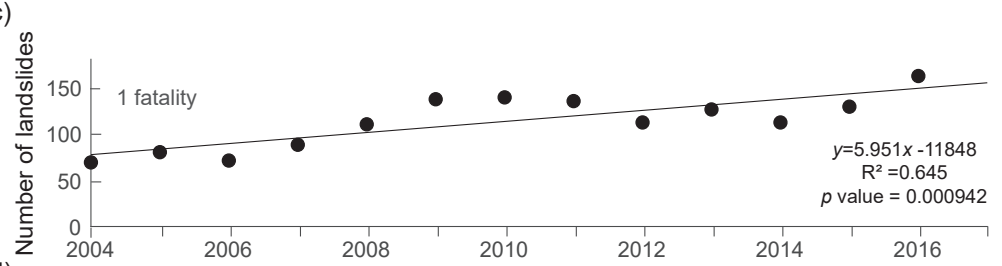

(d)

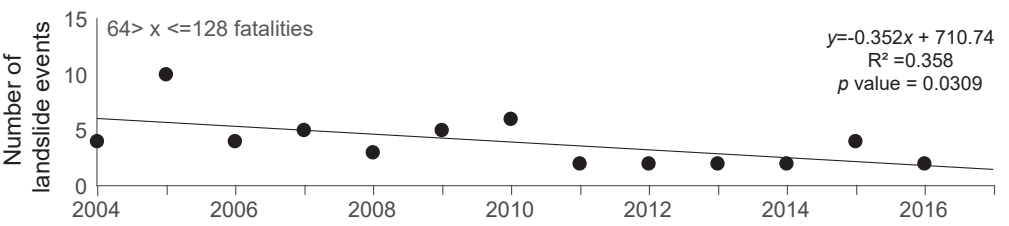

(e) $\begin{aligned} & \text { Multi-fatality landslide events } \\ & \text { (excluding } 64 \text { to } 128 \text { fatalities) }\end{aligned}$

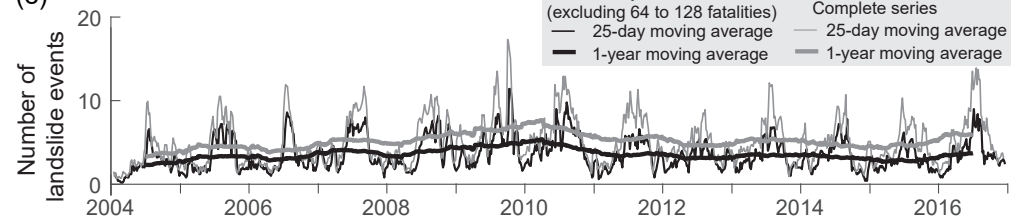

(f)
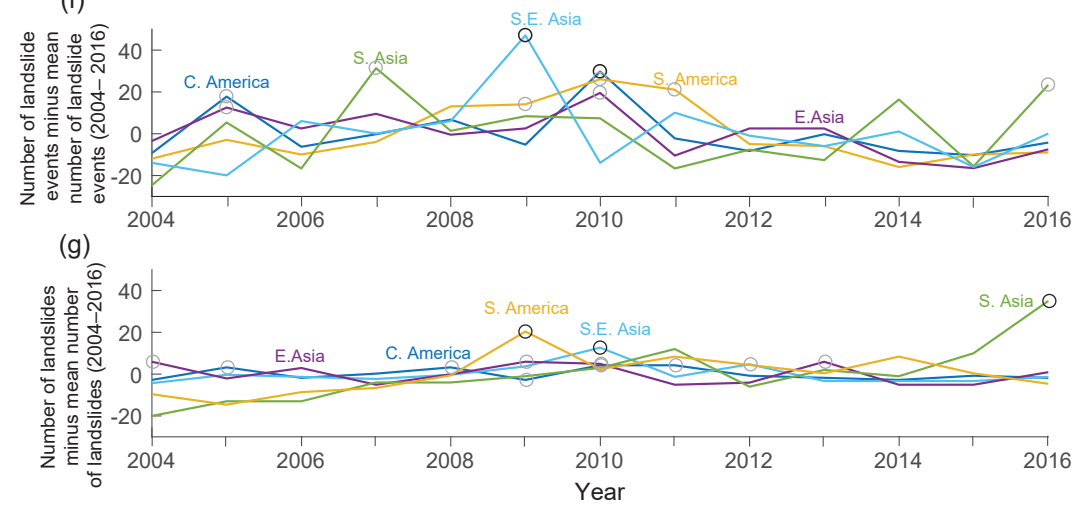

Figure 6. (a) The occurrence of non-seismically triggered landslide events from 2004 to 2016: 25-day and 1-year moving average (see also Fig. 2). (b) The number of fatalities from non-seismically triggered landslide events from 2004 to 2016 by pentad with 25 -day moving average. (c) Number of single-fatality landslides 2004 to 2016. (d) Number of landslide events incurring 64 to 128 fatalities per event from 2004 to 2016. (e) Comparison of the complete landslide series (Fig. 6a) and multi-fatality landslide series (excluding the 64- to 128fatality class). (f) Anomalies in landslide event occurrence by year by geographical region (multi-fatality events). (g) Anomalies in landslide occurrence by year, by geographical region (single-fatality events). Values greater than 1 standard deviation from the mean are shown by a grey circle. Values greater than 2 standard deviations from the mean are shown by a black circle. 


\subsection{Medium-term trend in landslide occurrence}

There was a general increase in recorded landslide occurrence between 2004 and March 2010, followed by a general decrease in landslide occurrence through April 2015, after which landslide incidence has generally increased (Fig. 6a). Petley (2012) identified improvements in the reporting of single-fatality landslides as contributing to the general increase in events in the fatal landslide record from 2004 to 2010. The number of fatalities resulting from non-seismic landslide events between 2004 and 2016 was 55997. Figure $6 \mathrm{~b}$ shows that the pentad series of fatality is very noisy; the data do not contain an increasing or decreasing trend, nor are there distinguishable medium-term peaks in the data. Very few landslide events generated more than 1000 fatalities $(0.1 \%)$, and only one landslide resulted in more than 5000 fatalities. This was the Kedarnath landslide in June 2013 in Uttarakhand state, India, which was caused by extreme meteorological conditions that generated flooding and two large landslides in a mountainous area occupied by thousands of religious pilgrims (Allen et al., 2016).

Landslide events by the number of fatalities are grouped by the infinite series $(1,2,4,8,16 \ldots)$. There is a significant increasing trend in single-fatality landslides (Fig. 6c); $29 \%$ of landslides were single-fatality events. There is also a weaker decreasing trend in landslide events resulting in 64 to 128 fatalities (Fig. 6d); $1 \%$ of landslide events were in this group. No other grouping contained a significant trend with time. Both the single-fatality and 64- to 128 -fatality series are above the regression line in 2010 (Fig. 6c and d). Removing these two groups from the global series (Fig. 6e), it is evident that single-fatality events enhanced the peak around 2010 and in 2016.

By year, different geographical regions experience above or below average landslide activity (multi-fatality landslide events, Fig. 6f; single-fatality landslides, Fig. 6g). In 2005, 2009, 2010 and 2011, several regions experienced greater than average landslide occurrence simultaneously (Fig. $6 \mathrm{f}$ and g). The high impact of landslides globally in 2010 has been discussed by previous authors (Kirschbaum et al., 2012, 2015; Petley, 2012; Sepúlveda and Petley, 2015). The geographical pattern of rainfall-triggered landslide events in 2009 and 2010 reflects the occurrence of a moderate El Niño in 2009 and a moderate La Niña in 2010 (NOAA, 2018b).

In Central America, Kirschbaum et al. (2012) showed that rainfall was significantly above average in the summer months in 2010, particularly in September. This increase was linked to the known impacts of La Niña events on tropical cyclone frequency and track (e.g. Elsner et al., 1999; Curtis et al., 2007). By number, 2010 was the year in which the most landslides (17 events, compared with an average 6 events per year), were directly associated with tropical cyclones in reports or related to storm tracks (based on NOAA, 2018c). Although these landslide events only equate to $35 \%$ of all rainfall-triggered landslide events within 2010, the remain- ing $65 \%$ of events, not triggered by a tropical cyclone all occurred during the hurricane season (May to November), are likely due to unsettled weather associated with warm sea surface temperatures (SSTs) in the region. Central America receives tropical cyclones from the Atlantic basin and the North Pacific basin (NOAA, 2018c). Storms from the Atlantic basin may make landfall along the eastern coastline of Central America and travel inland, occasionally retaining enough energy to cross over into the Pacific. Storms that have crossed over basins or new storms, which have formed in the northeast Pacific basin, may make landfall on the western coast of Central America. Not only was the frequency of landfalling tropical storms and hurricanes elevated from both basins in 2010, but the track of these storms intercepted populated areas in steep terrain (NOAA, 2018c). The majority of rainfall-triggered landslide events in Central America in 2010 were in Mexico and Guatemala (43 and 37\% respectively). In Guatemala, eight landslide events were triggered by tropical storm Agatha in late May 2010, causing 182 fatalities. Four landslide events were associated with Hurricane Alex, which travelled up the east coast of Guatemala, Honduras and then inland to Mexico in late June-July 2010. Hurricane Karl then made landfall on the east coast of Mexico in September: two landslide events are associated with this storm (killing 12), but a succession of fatal landslides in the states of Oaxaca, Chiapis and Puebla, through which the hurricane passed, was noted in the weeks following the storm.

Sepúlveda and Petley (2015) observed a weak correlation between La Niña conditions in late 2010-2011 and heightened landslide activity in Colombia and Venezuela. Considering a longer time series (2004 to 2016), this study identifies above average landslide activity in several nations in South America in 2009 and 2011. In Brazil, 54\% of all rainfall-triggered events occurred between 2009 and 2011. Activity peaked in December 2009 to April 2010 (El Niño) and January 2011 (La Niña), corresponding with the seasonal El Niño-Southern Oscillation (ENSO) rainfall patterns observed by Grimm and Tedeschi (2009). The number of landslide events in Venezuela and Colombia between 2009 and 2011 peaked in November 2010, associated with positive rainfall anomalies during the austral summer La Niña (Tedeschi et al., 2013).

The majority of landslide events in East Asia occur in China (83\%); in 2010, $87 \%$ of all rainfall-triggered events were located in China, and rainfall-triggered landslide occurrence (67 landslide events) was above the mean (45 landslide events). From a shorter period of observation, Kirschbaum et al. (2012) identified a high incidence of rainfall-triggered landslides (fatal and non-fatal) in central eastern China in 2010, particularly in July and August, corresponding with a peak in rainfall. Rainfall-triggered landslides were above average for most months in 2010 in China, but the period of May to September was very active (57 landslide events compared with an average 38). The East Asian subtropical summer monsoon (a component of the East Asian monsoon) has 


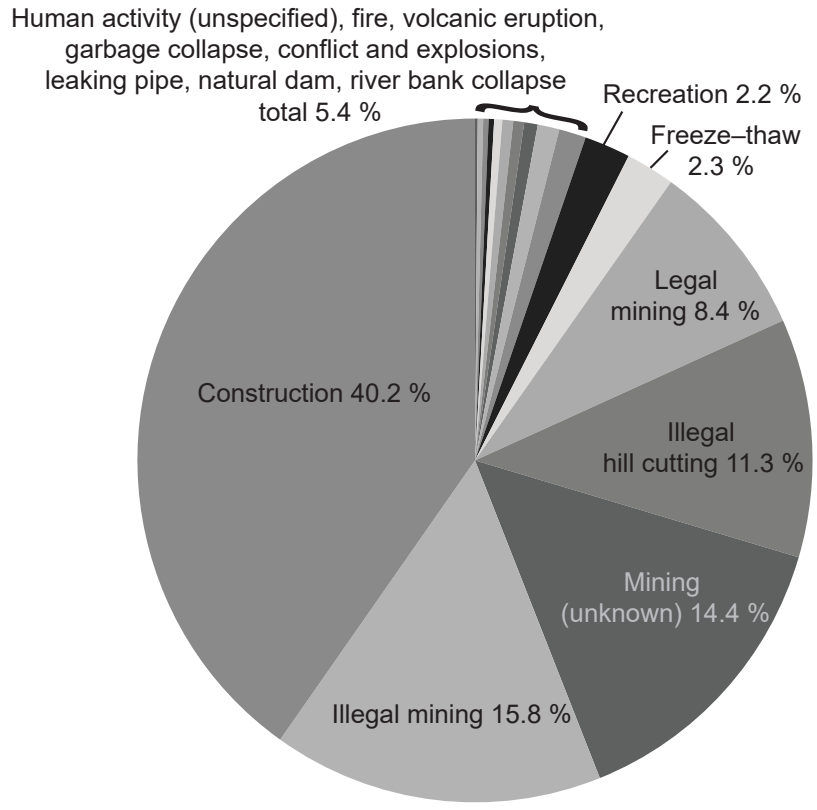

Figure 7. Distribution of triggers of NSNR landslide events (770 events).

a significant effect on seasonal variations in rainfall across China (He and Liu, 2016), and rainfall patterns alter in response to ENSO conditions (Yang and Lau, 2004; He et al., 2007; Zhou et al., 2014).

In China in 2010 there were fewer than average landslide events triggered by tropical cyclones from the northwest Pacific basin. There was low typhoon activity due to the rapid transition from the 2009-2010 El Niño to the 2010-2011 La Niña, which altered airflows in the northwest Pacific basin (Kim et al., 2012). Conversely, in the Philippine domain, tropical cyclone occurrence was above average in July to December 2009 (Corporal-Lodangco et al., 2015). During the northern hemispheric summer months of an El Niño, the genesis location of tropical cyclones shifts eastwards (Chan, 1985, 2000; Chia and Ropelewski, 2002). In these conditions, cyclones travel further before they may make landfall, enabling them to strengthen (Camargo and Sobel, 2005), and there is a tendency for more storms to affect the northerncentral Philippines (Lyon and Camargo, 2009). In 2009, 67 \% of rainfall-triggered landslide events in the Philippines were associated with tropical cyclones: 60 landslide events compared with an average 12 triggered by tropical cyclones. As noted previously, many of these were triggered on the same day (8 October 2009) by Typhoon Parma.

Although the peak in landslides in Southeast Asia in 2009 is dominated by typhoon-triggered landslides in the Philippines, there was an increase in landslides in Indonesia (33 landslide events compared with an average of 24 per year); of these 24 events were triggered by rainfall, 8 by mining and one trigger was not known. Rainfall-triggered land- slide events were very slightly above average in Indonesia in 2009 but it was the events triggered by human activity that contributed most to the anomalous landsliding in Indonesia. These landslides are discussed in the next section.

Between 2004 and 2016, four El Niño events occurred: weak El Niño (2004-2005, 2006-2007), strong El Niño (2009-2010) and very strong El Niño (2014/2016; NOAA, 2018b). Weak La Niña was observed in 2005-2006, 20082009 and 2016, and strong La Niña occurred in 2007-2008 and 2010-2011 (NOAA, 2018b). There does not appear to be a consistent relationship between ENSO phase and the regional distribution of landslides, although elevated regional rainfall (and thus landslides) has been associated with ENSO SST anomalies. The peak in landslide events in Central America in 2005 is composed predominantly of tropical storm and hurricane-triggered landslides in El Salvador, Mexico, Guatemala and Honduras. The 2005 North Atlantic hurricane season was the most active since records began in 1851, driven by high SSTs in the tropical North Atlantic $\left(10-20^{\circ} \mathrm{N}\right)$ linked with global warming and the 2004/2005 El Niño (Trenberth and Shea, 2006). Landslide events were also above average in 2005 in East Asia: most events occurring in China, triggered by monsoon rainfall. In South Asia, landslide events peaked in 2007, 2014 and 2016, the majority associated with monsoon rainfall in Bangladesh, India, Nepal and Pakistan. Variability in rainfall from the South Asian monsoon is related to the interaction between SSTs in the Indian Ocean Dipole and ENSO (e.g. Ashok and Saji, 2007; Lu et al., 2017).

The complexity of climate systems means it is not possible to draw conclusions on the relationship between climate mode and landslide occurrence from this 13-year global dataset. However, longer local records show promise at unpicking the impact of climate cycles on landslides.

\subsection{NSNR landslide triggers}

Of the 4862 non-seismic landslide events in the complete database, $770(16 \%)$ were generated by a NSNR trigger and resulted in a total of 3725 fatalities (Fig. 7). The majority of landslides were triggered by mining (232 multi-fatality landslide events, 67 single-fatality landslides), construction (170 multi-fatality landslide events, 140 single-fatality landslides) or illegal hill cutting (60 multi-fatality landslide events, 27 single-fatality landslides); the majority of fatalities in all cases were people at work (90, 76 and $84 \%$ respectively). Globally there is a statistically significant increase in events by these three triggers (Fig. 8a, b and c); multi-fatality landslide events are differentiated from single-fatality landslides, which increased with time independent of trigger (Fig. 6c). By country, most construction-triggered landslide events occurred in India (28\%), followed by China (9\%), Pakistan $(6 \%)$, the Philippines (5\%), Nepal (5\%) and Malaysia (5\%; Fig. 9a). On average construction-triggered landslide events have killed 3 people per event, but a particularly severe land- 

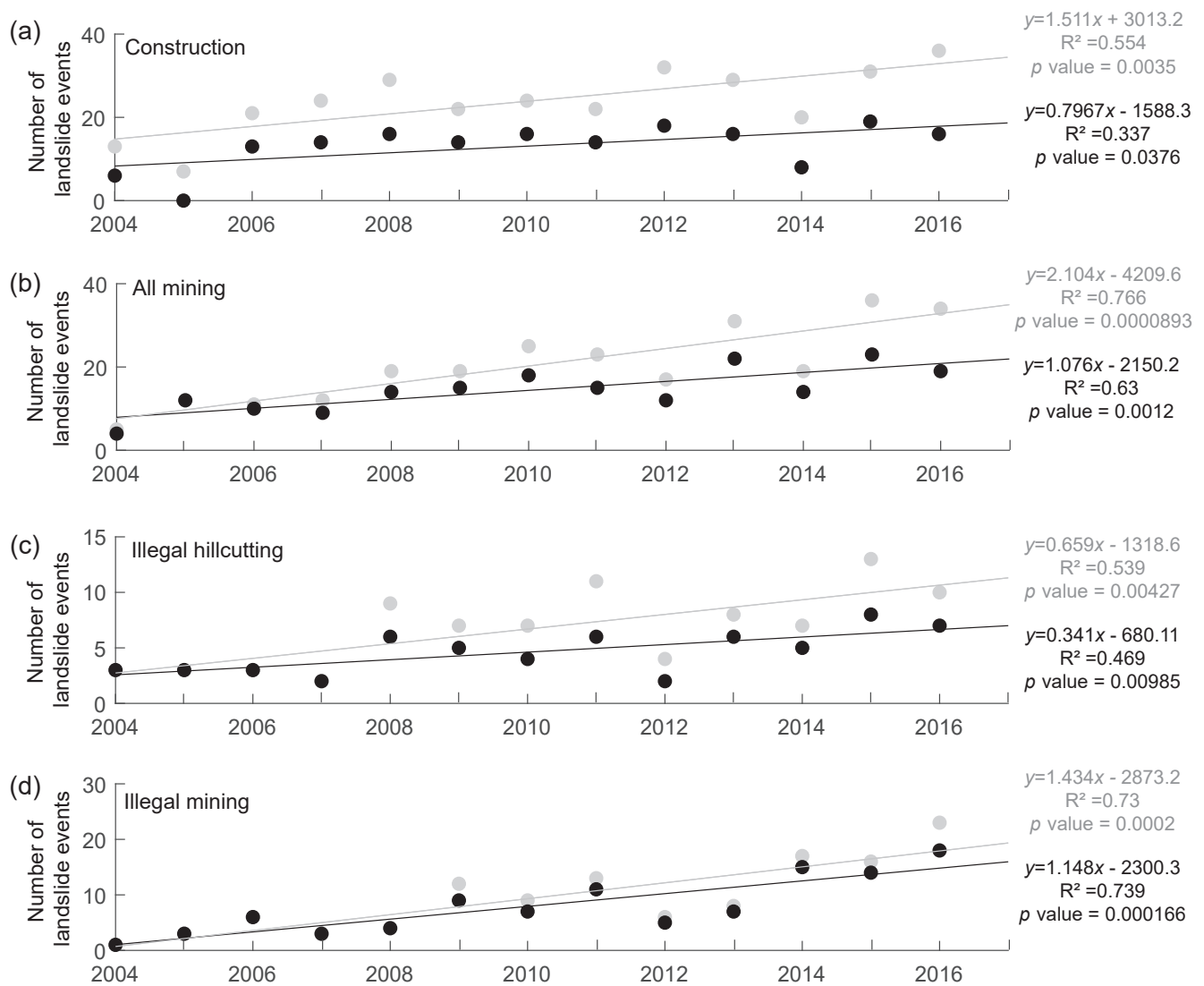

$$
\begin{gathered}
R^{2}=0.73 \\
p \text { value }=0.0002
\end{gathered}
$$

$y=1.148 x-2300.3$

$\mathrm{R}^{2}=0.739$ $p$ value $=0.000166$

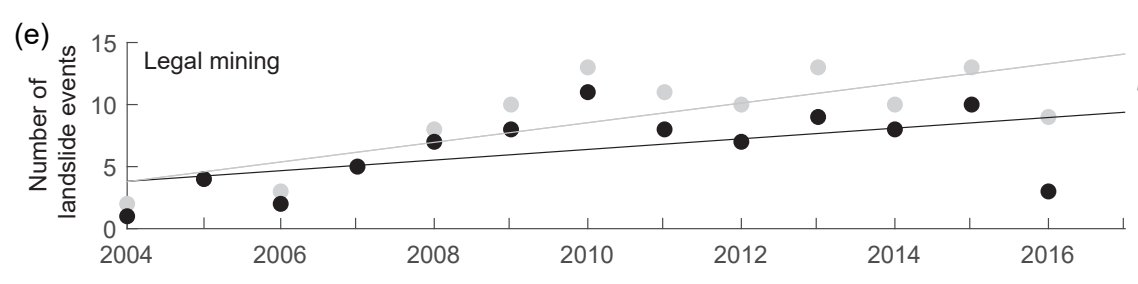

$y=0.791 x-1581.8$ $\mathrm{R}^{2}=0.636$ $p$ value $=0.001097$ $y=0.429 x-855.04$
$R^{2}=0.286$ $p$ value $=0.0599$

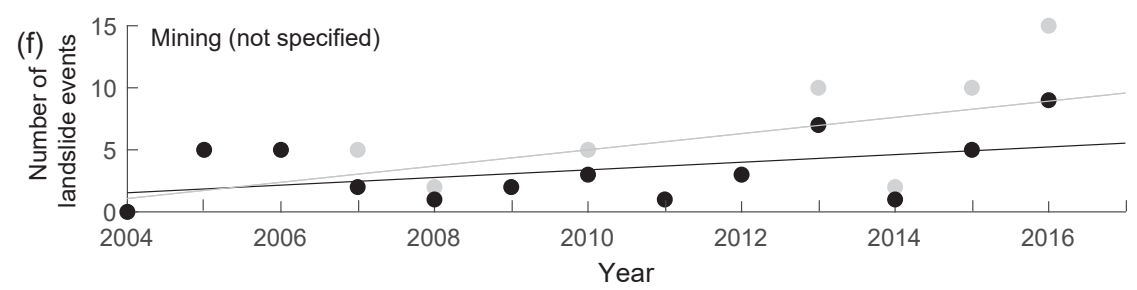

$y=0.653 x-1309.2$ $R^{2}=0.35$ $p$ value $=0.03304$ $y=0.308 x-615.08$ $\mathrm{R}^{2}=0.203$ $p$ value $=0.1228$

Figure 8. Number of landslide events triggered per year by (a) construction, (b) mining, (c) illegal hill cutting, (d) illegal mining, (e) legal mining and (f) mining (not specified). The black series contains only multi-fatality landslide events. The grey series contains single and multi-fatality landslide events.

slide in Shenzhen, China, in December 2015 killed 77 people. The event involved the collapse of construction waste on worker quarters in an industrial site. Interestingly, the context in which the landslides occur differs between countries. In China, the majority of events (52\%) occur in urban construction sites, while very few landslides occur on roads $(7 \%)$. Conversely, in India and Nepal, 30 and $43 \%$ of landslide events triggered by construction occurred on roads.
Transportation is a "crucial driver of development" (World Bank, 2018b); however, in mountain regions roads are closely connected with landslide risk (Lennartz, 2013). The road network in Nepal has quadrupled in length over the last 18 years (Govt. of Nepal, 2016), and in India it has nearly tripled in length in 24 years (Govt. of India, 2016). Population growth is frequently accompanied by the expansion of infrastructure and settlements (Gardner and Dekens, 2007), 
and this is true in India and Nepal, which have grown by $\sim 7 \%$ between 2010 and 2015 (World Bank, 2018a). Both countries are on a trajectory to expand their national road networks further. Increased landslide activity in the Himalayan region has been associated with road construction (Ives and Messerli, 1989; Haigh et al., 1989; Valdiya, 1998; Barnard et al., 2001; Petley et al., 2007; Sati et al., 2011; Singh et al., 2014). Hearn and Shakya (2017) highlighted that road construction without proper route choice, engineering design and management of spoil increases landslide susceptibility. Fatal landslides triggered by road construction indicate that excavation may not always be undertaken with due care and appropriate slope engineering. Furthermore, the coincidence of construction worker and road user fatalities from the same landslide suggests that there is pressure to keep roads under construction open. Ives and Messerli (1989) emphasised the economic impact when roads are closed.

Between 2004 and 2016, China experienced a $6 \%$ growth in population to 1.379 billion and a $16 \%$ rise in the proportion of the population living in urban areas (World Bank, 2018a). Urban growth in China is driven by political policy for economic growth; economic reforms from 1978 opened China's markets to foreign investors and relaxed migration controls, prompting rapid rural-urban migration (Ma, 2002; Anderson and Ge, 2004). Although urbanisation is encouraged by China to increase domestic consumption, urban growth is often uncontrolled (Fang and Pal, 2016), leading to rapid land conversion, dispersion and fragmentation of development (Schneider and Woodcock, 2008). Critically, many of China's largest cities are bounded by mountains, and urban sprawl is encroaching on land unsuitable for development (Yu et al., 2011). Reports in the database indicate that fatal landslides in urban construction sites in China often occurred when engineered cut slopes failed above the construction site (e.g. Zhang et al., 2012), from improper construction of foundations leading to building collapse before completion (e.g. Srivastava et al., 2012) or from mismanagement of construction and demolition waste (e.g. Yang et al., 2017). In these entirely preventable circumstances, explicit national regulation and enforcement should reduce construction-related landslide impact in China.

The increase in events triggered by mining is driven by the increase in landslides triggered by illegal or unregulated extraction (Fig. 8d); landslides triggered by legal mining (Fig. 8e) or where the legitimacy of the mining is unknown (Fig. 8f) do not show a statistically significant trend. By country, India (12\%), Indonesia (11.7\%), China (10\%), Pakistan (7\%) and Philippines (7\%) contribute most to the record of landslides triggered by mining (Fig. 9b). Fatal landslides triggered by illegal mining practises have occurred in 32 countries (Fig. 9c). By number of events, Indonesia (24) and India (15) rank the highest, but by number of fatalities Myanmar (403 fatalities from 9 landslide events) stands out. Shifts in spending power and the infusion of the internet and smart technology in daily life have driven an exponential in- crease in the consumption of electronics, placing pressure on the demand for rare earth elements (Dutta et al., 2016). Furthermore, growth in the precious stone market fuelled by both economic uncertainty and a growing middle class in Asian nations such as China, where gemstones are a key part of cultural heritage (The Economist, 2011), is thought to have led to an increase in the number of small-scale mining operations globally (Hruschka and Echavarría, 2011) and the upscaling of small-scale mines to larger-scale operations. Fatal landslides in Myanmar (Burma) have significantly increased because of the unregulated expansion in jade mining within the Kachin state. Critically, the high value of jade and lack of enforced operator accountability appear to be driving poor mining practises, which place workers and local residents at risk of slope collapse (Global Witness, 2015). Demand for rare earth elements and gemstones is thus driving an increase in mining-related landslides, with the potential for landslide occurrence to rival that associated with rural road expansion.

Cutting slopes for the purposes of obtaining earth surface materials, or to alter slope geometry during construction, may result in slope failure if the site is not properly engineered. The term hill cutting is used here in relation to discrete slopes that have been altered without permission for the purposes of small-scale construction, earth material extraction or agriculture. Hill cutting is most strongly associated with urban areas in Bangladesh in the academic literature (e.g. Chittagong; Ahmed, 2015 or Syhlet; Islam et al., 2006). In the fatal landslide database it is an increasing problem in Bangladesh, India and Nepal (Figs. 8c and 9d). Most fatalities occurred as people collected hillslope materials for construction of their housing in rural communities, and reports indicate those involved were from poor families living in informal settlements. In total, 11 of the 87 landslide events were directly related to the practice of using hillslope coloured clay for the decorative coating of houses for a religious festival; of these, 9 occurred in Nepal. Critically, children are often caught up in slides triggered by hill cutting in Nepal: at least $40 \%$ of landslide victims were children, while a further $25 \%$ of victims were a combination of adults (predominantly women) and children working together. Conversely, in Bangladesh the majority of victims were adults $(78 \%)$ of which $79 \%$ were male. In Nepal, India and Bangladesh, clay is an important local building material for housing, particularly in settlements not connected to the road network. There is a legal framework in Bangladesh to prevent hill cutting (Building Construction Act 1952 and 1990, and the Bangladesh Environmental Conservation Act 1995; Murshed, 2013). Building codes in Nepal provide basic guidance on slope stability, specifically slope excavation, identification of slope instability and construction of foundations (DUDBC, 1994); however, residents in rural communities may not have access to this information and be unaware of the hazard (Oven et al., 2008). Furthermore, in India it was noted that building regulations do not account for the geo-environmental context of the settlement, sometimes lack 

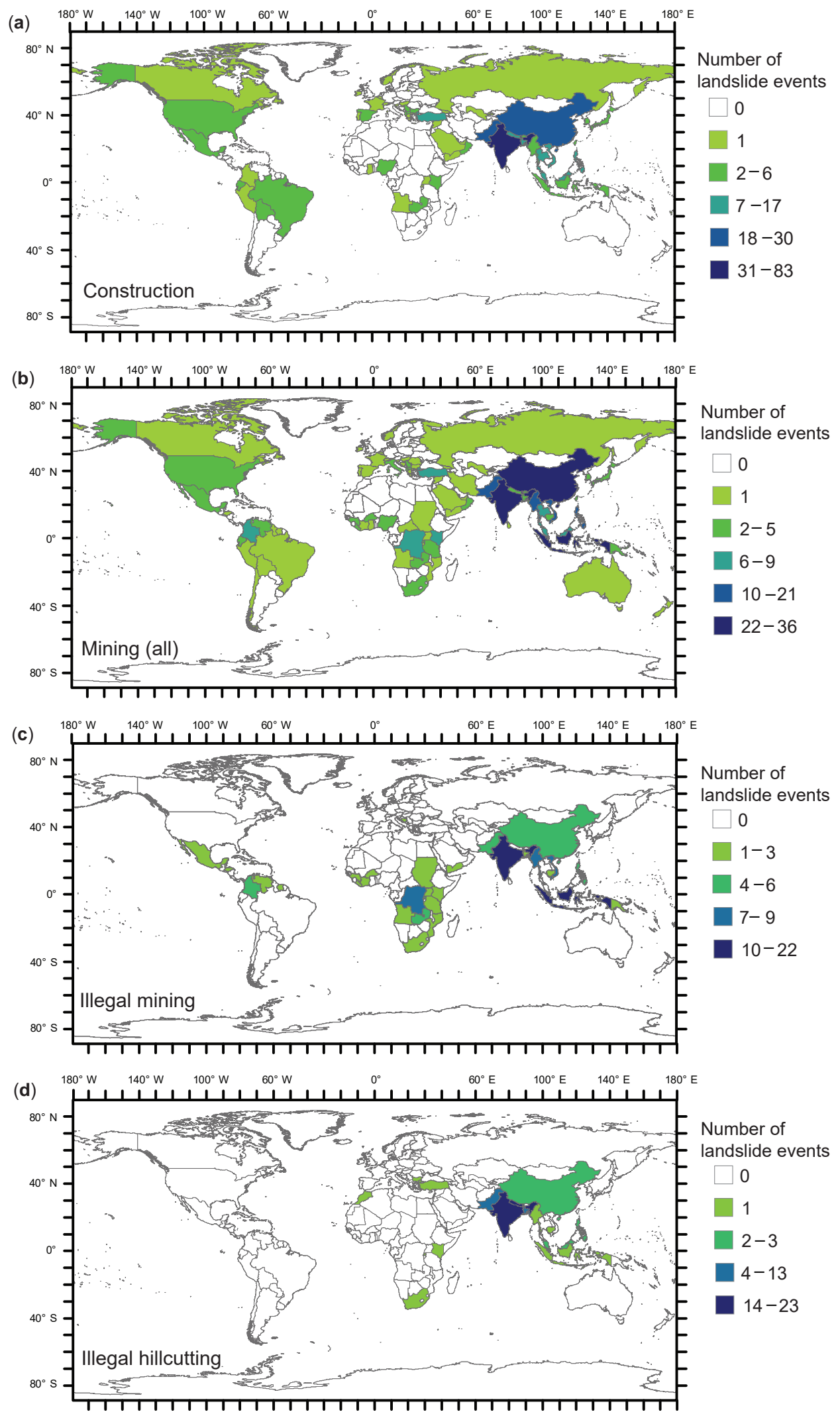

Figure 9. By country, the number of landslide events triggered by (a) construction, (b) mining, (c) illegal mining and (d) illegal hill cutting, between 2004 and 2016. 
clarity and are difficult to uphold due to a shortage of technical experts and inadequate provision to stop illegal activity (Kumar and Pushplata, 2015).

While this section discusses fatal landslides triggered by human activity, many rainfall-triggered landslides occur on slopes which have been modified during construction (82 landslide events), agriculture and forestry (45 landslide events) and mining (123 landslide events) or at sites where storage of waste has not been poorly managed (16 landslide events). Of course, it is expected that the majority of fatal landslides $(94 \%)$ will occur within settlement boundaries or along infrastructure, but it is evident from this database of events that human action damages slopes, increasing their susceptibility to fail.

\section{Discussion and conclusion}

With the benefit of a 13-year time series, this study builds on past analyses of the GFLD, not only providing an update on the spatial and temporal distributions of landslide impact but also serving to highlight the importance of annual climate variability in specific landslide-prone regions on the global record. In addition, it provides new insights into the impact of human activity on landslide incidence. The data do not indicate a discernible long-term increase or decrease in global landslide impact; rather, the record shows that there is considerable interannual variability in global landslide event incidence. The more active years have been associated with recognised regional patterns of rainfall, in part driven by global climate anomalies, but there is no simple relationship with, for example, ENSO. Relating climate modes to patterns of landsliding is challenging because of climate complexity and change, requiring datasets of 30 years or more. Increased understanding of the impact of ENSO diversity on regional climate will improve models forecasting seasonal rainfall distribution and landslide impact. This is particularly important in acutely affected areas such as India, China and Nepal.

Human disturbance (land use change) may be more detrimental to future landslide incidence than climate change (Crozier, 2010; Anderson and Holcombe, 2013), and this is evidenced by a number of studies (Innes, 1983; Glade, 2003; Soldati et al., 2004; Imaizumi et al., 2008; Borgatti and Soldati, 2010; Lonigro et al., 2015). A comprehensive review of climate-landslide studies by Gariano and Guzzetti (2016) found the majority of papers $(80 \%)$ showed a causal relationship between climate change and landslides. However, the authors highlight the significant uncertainties surrounding our current understanding of climate-landslide interaction. Specifically, the limited geographic scope of research, challenges in downscaling climate scenarios to slope stability models and complex interactions between natural and human induced drivers of landslide activity. Gariano and Guzzetti (2016) demonstrate that different climate variables will effect different landslide types and slope settings. There is a high confidence that glacial retreat and permafrost degradation will increase slope instabilities in high mountain areas in the long term, and high confidence that changes in heavy precipitation will affect some regions. However, there is low confidence in projections for shallow landslide activity in temperate and tropical regions because of the coincident effects of human land use practise (Seneviratne et al., 2012). Further research is required to evaluate the impact of climate change and human disturbance in different localities.

Our analyses have demonstrated that fatal landslide occurrence triggered by human activity is increasing, driven by construction, illegal mining and illegal hill cutting. Fatal landslides occur when construction and mining (1) do not apply appropriate slope engineering, (2) mismanage spoil and (3) do not undertake a feasibility assessment (Hearn and Shakya, 2017). Appropriate building regulations that account for the geo-environmental context of the settlement, provide clear guidance on engineering and are enforced by local technical experts are paramount in managing landslide risk associated with urbanisation and natural resource exploitation.

Holcombe et al. (2016) emphasised that planning policy alone is not sufficient to control landslide risk in developing nations. This is due to the rapid and informal nature of construction and low income of residents, who cannot finance expert guidance when building their homes. Settlements are often built on hazardous land around urban centres and on roadsides because of the benefits of service access and employment opportunities (Smyth and Royle, 2000; Oven et al., 2008; Lennartz, 2013; Anhorn et al., 2015). Hill cutting is the dominant driver of instability during informal construction (Holcombe et al., 2016), and our results indicate that fatal landslide events triggered by hill cutting are increasing in Bangladesh, India and Nepal. Several landslides were triggered when people cut slopes to collect coloured clay to decorate their houses for religious festivals. Here, communication of landslide risk by local non-governmental organisations (NGOs) could prevent future fatalities from this practice. Where governments are limited in capacity at a local level, NGOs are important in implementing disaster risk reduction (Jones et al., 2016), such as supporting communitybased slope engineering (e.g. Mossaic; Anderson and Holcombe, 2006).

Reporting of fatal landslides is likely to increase with the global growth in mobile technology and internet access, particularly in remote mountain regions. Furthermore, advances in web mining (data retrieval from the internet based on search criteria) and text mining (transforms unstructured data into structured to discover knowledge) using machine learning offer methods to improve capture of landslide reporting and data evaluation (e.g. Bhatia and Khalid, 2008; Kumar and Jaiswal, 2017). Global landslide databases are designed to capture general trends in landslide occurrence rather than provide data for local quantitative risk assessment. Continued collection of the database will develop our understand- 
ing of the effect of climate and human disturbance on global landslide impact. The dataset is a useful tool in identifying acutely landslide-prone parts of the world and specific local drivers of landslide impact, thereby highlighting locations which would benefit from further development in early warning technology, landslide risk assessment and community capacity building. This is in support of the future directions of the International Consortium on Landslides (AlcántaraAyala et al., 2017).

Data availability. The GFLD (2004 to 2016) data are available to view at ESRI ArcGIS online at https: //shefuni.maps.arcgis.com/apps/webappviewer/index.html?id= 98462998953c4f1fbd7caaa166373f63 (Froude and Petley, 2018). A full release of the database is scheduled for later in 2018. The release will be publicized on Dave's landslide blog: https://blogs.agu.org/landslideblog/ (last access: 18 July 2018). 


\section{Appendix A}

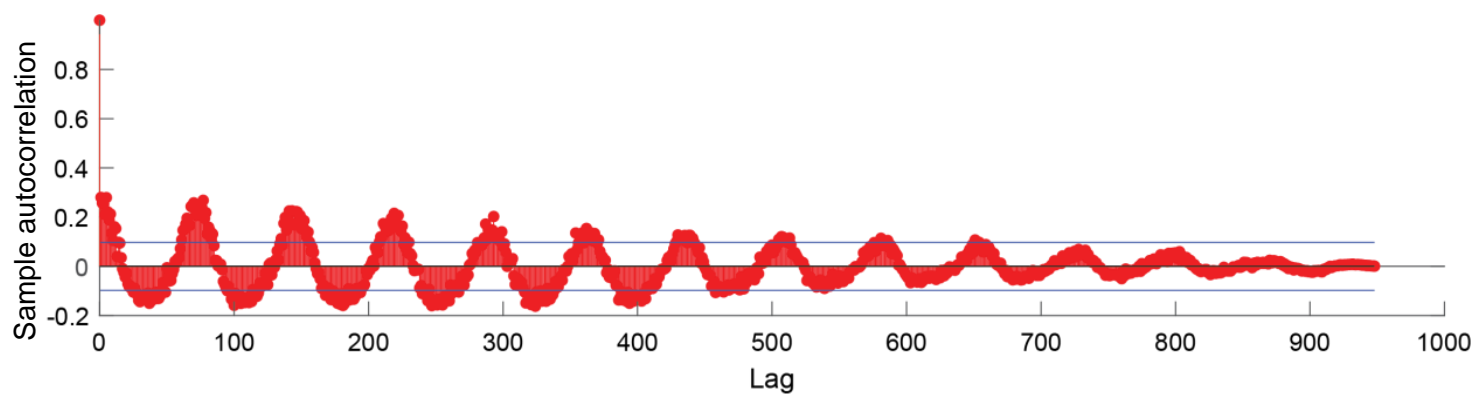

Figure A1. Sample autocorrelation plot for the pentad rainfall-triggered landslides. The $99 \%$ confidence interval is shown by the blue horizontal lines.

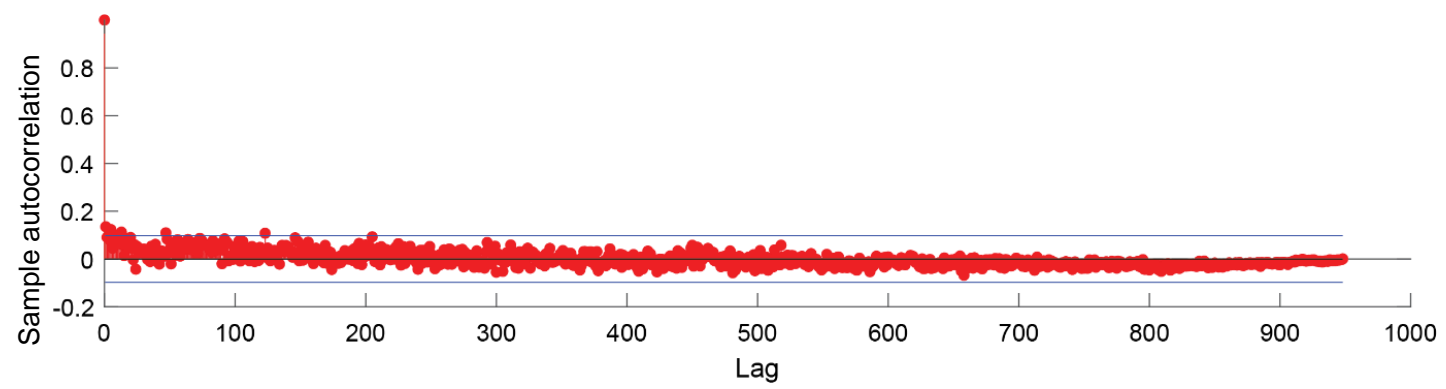

Figure A2. Sample autocorrelation plot for the pentad NSNR landslides. The $99 \%$ confidence interval is shown by the blue horizontal lines.

\section{Appendix B}

Table B1. Hierarchal linear regression results comparing the impact of seasonality in geographical regions with the global mean number of landslides per pentad through the annual cycle (see Fig. 4). The data series for each geographical region are sequentially added into the regression (such that the second row of the table is a regression of South Asia + SE Asia with the global series).

\begin{tabular}{lrrrr}
\hline Predictor variables & $N$ (cumulative) & $\%$ (of total $N$ ) & $R^{2}$ & $\Delta R^{2}$ \\
\hline + South Asia & 1295 & 31.50 & 0.4962 & \\
+ SE Asia & 2121 & 52.27 & 0.7365 & 0.2403 \\
+ East Asia & 2804 & 71.88 & 0.8618 & 0.1253 \\
+ South America & 3145 & 82.25 & 0.9129 & 0.0511 \\
+ Central America & 3340 & 88.03 & 0.9575 & 0.0446 \\
\hline
\end{tabular}


Supplement. The supplement related to this article is available online at: https://doi.org/10.5194/nhess-18-2161-2018-supplement.

Author contributions. DP developed the methodology (20022003) and has consistently collected the database since 2004. MF analysed the data and wrote up the results for this submission. DP contributed to writing.

Competing interests. The authors declare that they have no conflict of interest.

Acknowledgements. The research has been supported by the NERC/Newton Fund grant NE/N000315/1 and NE/N000315/2.

Edited by: Mario Parise

Reviewed by: two anonymous referees

\section{References}

Ahmed, B.: Landslide susceptibility mapping using multicriteria evaluation techniques in Chittagong Metropolitan Area, Bangladesh, Landslides, 12, 1077-1095, https://doi.org/10.1007/s10346-014-0521-x, 2015.

Alcántara-Ayala, I., Sassa, K., Mikoš, M., Han, Q., Rhyner, J., Takara, K., Nishikawa, S., Rouhban, B., and Briceño, S.: The 4th World Landslide Forum: Landslide Research and Risk Reduction for Advancing the Culture of Living with Natural Hazards, Int. J. Disaster Risk Sci., 8, 498-502, https://doi.org/10.1007/s13753017-0139-4, 2017.

Alexander, D.: Urban landslides, Prog. Phys. Geog.-Earth and Environment, 13, 157-189, https://doi.org/10.1177/030913338901300201, 1989.

Allen, S. K., Rastner, P., Arora, M., Huggel, C., and Stoffel, M.: Lake outburst and debris flow disaster at Kedarnath, June 2013: hydrometeorological triggering and topographic predisposition, Landslides, 13, 1479-1491, https://doi.org/10.1007/s10346-0150584-3, 2016.

Anderson, M. B.: Metropolitan areas and disaster vulnerability: a consideration for developing countries, in: Environmental Management and Urban Vulnerability, edited by: Kreimer, A. and Munasinghe, M., World Bank discussion paper \#18, World Bank, Washington DC, 1992.

Anderson, M. G. and Holcombe, E.: Community-Based Landslide Risk Reduction: Managing Disasters in Small Steps, World Bank Publications, 2013.

Anderson, M. G. and Holcombe, E. A.: Sustainable Landslide Risk Reduction in Poorer Countries, Proceedings of the Institution of Civil Engineers-Engineering Sustainability, 159, 23-30, 2006.

Anderson, G. and Ge, Y.: Do Economic Reforms Accelerate Urban Growth? The Case of China, Urban Stud., 41, 2197-2210, https://doi.org/10.1080/0042098042000268410, 2004.

Anhorn, J., Lennartz, T., and Nüsser, M., Rapid urban growth and earthquake risk in Musikot, mid-western hills, Nepal, Erdkunde, 69, 307-325, 2015.
Ashok, K. and Saji, N. H.: On the impacts of ENSO and Indian Ocean dipole events on sub-regional Indian summer monsoon rainfall, Nat. Hazards, 42, 273-285, https://doi.org/10.1007/s11069-006-9091-0, 2007.

Barnard, P. L., Owen, L. A., Sharma, M. C., and Finkel, R. C.: Natural and human-induced landsliding in the Garhwal Himalaya of northern India, Geomorphology, 40, 21-35, https://doi.org/10.1016/S0169-555X(01)00035-6, 2001.

Bennett, G. L., Miller, S. R., Roering, J. J., and Schmidt, D. A.: Landslides, threshold slopes, and the survival of relict terrain in the wake of the Mendocino Triple Junction, Geology, 44, 363366, https://doi.org/10.1130/G37530.1, 2016.

Bhatia, M. and Khalid, A. K.: Information retrieval and machine learning: Supporting technologies for web mining research and practice, Webology, 5, available at: http://www.webology.org/ 2008/v5n2/a55.html (last access: 15 February 2018), 2008.

Borgatti, L. and Soldati, M.: Landslides as a geomorphological proxy for climate change: A record from the Dolomites (northern Italy), Geomorphology, 120, 56-64, https://doi.org/10.1016/j.geomorph.2009.09.015, 2010.

Camargo, S. J. and Sobel, A. H.: Western North Pacific Tropical Cyclone Intensity and ENSO, J. Climate, 18, 2996-3006, https://doi.org/10.1175/JCLI3457.1, 2005.

Carrara, A., Crosta, G., and Frattini, P.: Geomorphological and historical data in assessing landslide hazard, Earth Surf. Proc. Land., 28, 1125-1142, https://doi.org/10.1002/esp.545, 2003.

Chan, J. C. L.: Tropical Cyclone Activity in the Northwest Pacific in Relation to the El Niño/Southern Oscillation Phenomenon, Mon. Weather Rev., 113, 599-606, https://doi.org/10.1175/15200493(1985)113<0599:TCAITN>2.0.CO;2, 1985.

Chan, J. C. L.: Tropical Cyclone Activity over the Western North Pacific Associated with El Niño and La Niña Events, J. Climate, 13, 2960-2972, https://doi.org/10.1175/15200442(2000)013<2960:TCAOTW>2.0.CO;2, 2000.

Chia, H. H. and Ropelewski, C. F.: The Interannual Variability in the Genesis Location of Tropical Cyclones in the Northwest Pacific, J. Climate, 15, 2934-2944, https://doi.org/10.1175/15200442(2002)015<2934:TIVITG>2.0.CO;2, 2002.

Corporal-Lodangco, I. L., Leslie, L. M., and Lamb, P. J.: Impacts of ENSO on Philippine Tropical Cyclone Activity, J. Climate, 29, 1877-1897, https://doi.org/10.1175/JCLI-D-14-00723.1, 2015.

Crozier, M. J.: Deciphering the effect of climate change on landslide activity: A review, Geomorphology, 124, 260-267, https://doi.org/10.1016/j.geomorph.2010.04.009, 2010.

Curtis, S., Salahuddin, A., Adler, R. F., Huffman, G. J., Gu, G., and Hong, Y.: Precipitation Extremes Estimated by GPCP and TRMM: ENSO Relationships, J. Hydrometeorol., 8, 678-689, https://doi.org/10.1175/JHM601.1, 2007.

Dowling, C. and Santi, P.: Debris flows and their toll on human life: a global analysis of debris-flow fatalities from 1950 to 2011, Natural Hazards: Journal of the International Society for the Prevention and Mitigation of Natural Hazards, 71, 203-227, https://doi.org/10.1007/s11069-013-0907-4, 2014.

DUDBC: Building Codes, Department of Urban Development and Building Construction, Ministry of Urban Development, Government of Nepal, Nepal, available at: http://www.dudbc.gov.np/ ?lang=en (last access: 20 February 2018), 1994.

Dutta, T., Kim, K.-H., Uchimiya, M., Kwon, E. E., Jeon, B.-H., Deep, A., and Yun, S.-T.: Global demand for rare earth resources 
and strategies for green mining, Environ. Res., 150, 182-190, https://doi.org/10.1016/j.envres.2016.05.052, 2016.

Elsner, J. B., Kara, A. B., and Owens, M. A.: Fluctuations in North Atlantic Hurricane Frequency, J. Climate, $\quad 12, \quad 427-437, \quad$ https://doi.org/10.1175/15200442(1999)012<0427:FINAHF>2.0.CO;2, 1999.

Espinoza Villar, J. C., Ronchail, J., Guyot, J. L., Cochonneau, G., Naziano, F., Lavado, W., De Oliveira, E., Pombosa, R., and Vauchel, P.: Spatio-temporal rainfall variability in the Amazon basin countries (Brazil, Peru, Bolivia, Colombia, and Ecuador), Int. J. Climatol., 29, 1574-1594, https://doi.org/10.1002/joc.1791, 2009.

ESRI: World Cities data, available at: http://www.arcgis.com/ home/item.html?id=dfab3b294ab24961899b2a98e9e8cd3d, last access: 19 February 2018.

Fang, Y. and Pal, A.: Drivers of Urban Sprawl in Urbanizing China - A Political Ecology Analysis, Environ. Urban., 28, 599-616, https://doi.org/10.1177/0956247816647344, 2016.

Froude, M. J. and Petley, D. N.: Global Fatal Landslide Database Web Application: non-seismic landslide events between 2004 and 2016, available at: https://shefuni.maps.arcgis.com/apps/webappviewer/index. html id=98462998953c4f1 fbd7caaa166373f63, last access: 9 August 2018.

GADM: GADM maps and data, available at: https://gadm.org/ index.html, last access: 1 June 2017.

Garcia, N., Ferreira, R. N., and Latrubesse, E. M.: Ch1 Climate and Geomorphologic-related Disasters in Latin America, in: Natural Hazards and Human-Exacerbated Disasters in Latin America, Special Volumes of Geomorphology, edited by: Latrubesse, E. M., Elsevier, Nature, Amsterdam, the Netherlands, 550 pp., 2009.

Gardner, J. S. and Dekens, J.: Mountain hazards and the resilience of social-ecological systems: lessons learned in India and Canada, Nat. Hazards, 41, 317-336, https://doi.org/10.1007/s11069-006-9038-5, 2007.

Gariano, S. L. and Guzzetti, F.: Landslides in a changing climate, Earth-Sci. Rev., 162, 227-252, https://doi.org/10.1016/j.earscirev.2016.08.011, 2016.

Glade, T.: Landslide occurrence as a response to land use change: a review of evidence from New Zealand, Catena, 51, 297-314, https://doi.org/10.1016/S0341-8162(02)00170-4, 2003.

Glade, T. and Crozier, M. J.: The Nature of Landslide Hazard Impact, in: Landslide Hazard and Risk, John Wiley \& Sons Ltd, Chichester, England, 41-74, 2005.

Global Witness: Jade: Myanmar's “big state secret”, Global Witness Report, October 2015, available at: http://globalwitness.org (last access: 15 December 2016), 2015.

Google Earth: available at: https://earth.google.com/web/, last access: 8 June 2018.

Google Maps: available at: https://www.google.co.uk/maps, last access: 8 June 2018.

Govt. of India: Basic Road Statistics of India 2015-2016, Ministry of Road Transport and Highways, Transport Research Wing, Government of India, New Delhi, India, 2016.

Govt. of Nepal: Statistics of strategic road network SSRN 2015/2016, Department of Roads, Ministry of Physical Infrastructure and Transport, Government of Nepal, Nepal, 2016.
GPCC: Global Precipitation Climatology Centre monthly precipitation dataset, file: precip.mon.combined.total.v7.nc, available at: https://www.esrl.noaa.gov/psd/data/gridded/data.gpcc.html, last access: 10 February 2018.

Grimm, A. M. and Tedeschi, R. G.: ENSO and Extreme Rainfall Events in South America, J. Climate, 22, 1589-1609, https://doi.org/10.1175/2008JCLI2429.1, 2009.

Guha-Sapir, D., Below, R., and Hoyois, P. H.: EM-DAT: International Disaster Database, Université Catholique de Louvain, Brussels, Belgium, available at: http://www.emdat.be, last access: 19 February 2018.

Haigh, M. J., Rawat, J. S., and Bartarya, S. K.: Environmental Indicators of Landslide Activity along the Kilbury Road, Nainital, Kumaun Lesser Himalaya, Mt. Res. Dev., 9, 25-33, https://doi.org/10.2307/3673462, 1989.

Hallegatte, S., Vogt-Schilb, A., Rozenberg, J., and Bangalore, M.: Unbreakable: Building the Resilience of the Poor in the Face of Natural Disasters, World Bank Publications, Washington, USA, 201 pp., 2016.

He, J. and Liu, B.: The East Asian subtropical summer monsoon: Recent progress, J. Meteorol. Res., 30, 135-155, https://doi.org/10.1007/s13351-016-5222-z, 2016.

He, J., Ju, J., Wen, Z., Junmei, L., and Jin, Q.: A review of recent advances in research on Asian monsoon in China, Adv. Atmos. Sci., 24, 972-992, https://doi.org/10.1007/s00376-007-0972-2, 2007.

Hearn, G. J. (Ed.): Slope Engineering for Mountain Roads. Geological Society, London, Engineering Geology Special Publications, 24, 2011.

Hearn, G. J. and Shakya, N. M.: Engineering challenges for sustainable road access in the Himalayas, https://doi.org/10.1144/qjegh2016-109, 2017.

Hervás, J. and Bobrowsky, P.: Mapping: Inventories, susceptibility, hazard and risk, in: Landslides - Disaster Risk Reduction, edited by: Sassa, K. and Canuti, P., Springer, Berlin, Germany, 321349, 2009.

Holcombe, E. A., Beesley, M. E. W., Vardanega, P. J., and Sorbie, R.: Urbanisation and landslides: hazard drivers and better practices, Proc. Inst. Civ. Eng.-Geotech. Eng., 169, 137-144, https://doi.org/10.1680/jcien.15.00044, 2016.

Hong, Y., Adler, R., and Huffman, G.: Use of satellite remote sensing data in the mapping of global landslide susceptibility, Nat. Hazards, 43, 245-256, https://doi.org/10.1007/s11069-0069104-z, 2007.

Hruschka, F. and Echavarría, C., Rock-Solid Chances for Responsible Artisanal Mining, Series on Responsible ASM No.3, Alliance for Responsible Mining, 2011.

Hungr, O., Leroueil, S., and Picarelli, L.: The Varnes classification of landslide types, an update, Landslides, 11, 167-194, https://doi.org/10.1007/s10346-013-0436-y, 2014.

Imaizumi, F., Sidle, R. C., and Kamei, R.: Effects of forest harvesting on the occurrence of landslides and debris flows in steep terrain of central Japan, Earth Surf. Proc. Land., 33, 827-840, https://doi.org/10.1002/esp.1574, 2008.

Innes, J. L.: Lichenometric dating of debris-flow deposits in the Scottish Highlands, Earth Surf. Proc. Land., 8, 579-588, https://doi.org/10.1002/esp.3290080609, 1983.

Islam, M. S., Jahid Hasan, G. M., and Chowdhury, M. A. I.: Destroying hills in the northeastern part of Bangladesh: A qualitative assessment of extent of the problem and 
its probable impact, Int. J. Environ. Sci. Te., 2, 301-308, https://doi.org/10.1007/BF03325890, 2006.

Ives, J. D. and Messerli, B.: The Himalayan Dilemma: Reconciling Development and Conservation, The United Nations University, Routledge, London, 1989.

Jones, S., Oven, K. J., and Wisner, B.: A comparison of the governance landscape of earthquake risk reduction in Nepal and the Indian State of Bihar, Int. J. Disast. Risk Re., 15, 29-42, https://doi.org/10.1016/j.ijdrr.2015.10.011, 2016.

Kim, J.-H., Ho, C.-H., Kim, H.-S., and Choi, W.: 2010 Western North Pacific Typhoon Season: Seasonal Overview and Forecast Using a Track-Pattern-Based Model, Weather Forecast., 27, 730743, https://doi.org/10.1175/WAF-D-11-00109.1, 2012.

Kirschbaum, D. B., Adler, R., Hong, Y., Hill, S., and LernerLam, A.: A global landslide catalog for hazard applications: method, results, and limitations, Nat. Hazards, 52, 561-575, https://doi.org/10.1007/s11069-009-9401-4, 2010.

Kirschbaum, D., Adler, R., Adler, D., Peters-Lidard, C., and Huffman, G.: Global Distribution of Extreme Precipitation and HighImpact Landslides in 2010 Relative to Previous Years, J. Hydrometeorol., 13, 1536-1551, https://doi.org/10.1175/JHM-D12-02.1, 2012.

Kirschbaum, D., Stanley, T., and Zhou, Y.: Spatial and temporal analysis of a global landslide catalog, Geomorphology, 249, 415, https://doi.org/10.1016/j.geomorph.2015.03.016, 2015.

Kubota, H., Shirooka, R., Matsumoto, J., Cayanan, E. O., and Hilario, F. D.: Tropical cyclone influence on the long-term variability of Philippine summer monsoon onset, Prog. Earth Planet Sci., 4, 27, https://doi.org/10.1186/s40645-017-0138-5, 2017.

Kumar, A. and Jaiswal, A.: Empirical Study of Twitter and Tumblr for Sentiment Analysis using Soft Computing Techniques, in: Proceedings of the World Congress on Engineering and Computer Science, vol. 1, iaeng.org, available at: http://www.iaeng. org/publication/WCECS2017/WCECS2017_pp472-476.pdf (last access: 11 July 2018), 2017.

Kumar, A. and Pushplata: Building regulations for hill towns of India, HBRC Journal, 11, 275-284, https://doi.org/10.1016/j.hbrcj.2014.06.006, 2015.

Lee, C.-F., Huang, W.-K., Chang, Y.-L., Chi, S.-Y., and Liao, W.C.: Regional landslide susceptibility assessment using multistage remote sensing data along the coastal range highway in northeastern Taiwan, Geomorphology, 300, 113-127, https://doi.org/10.1016/j.geomorph.2017.10.019, 2018.

Lennartz, T.: Constructing Roads-Constructing Risks? Settlement Decisions in View of Landslide Risk and Economic Opportunities in Western Nepal, Mt. Res. Dev., 33, 364-371, https://doi.org/10.1659/MRD-JOURNAL-D-13-00048.1, 2013.

Lonigro, T., Gentile, F., and Polemio, M., The influence of climate variability and land use variations on the occurrence of landslide events (Subappennino Dauno, Southern Italy), Rend. Online Soc. Geol. Ital., 35, 192-195, https://doi.org/10.3301/ROL.2015.98, 2015.

Lu, B., Ren, H.-L., Scaife, A. A., Wu, J., Dunstone, N., Smith, D., Wan, J., Eade, R., MacLachlan, C., and Gordon, M.: An extreme negative Indian Ocean Dipole event in 2016: dynamics and predictability, Clim. Dynam., 51, 1-12, https://doi.org/10.1007/s00382-017-3908-2, 2017.

Lyon, B. and Camargo, S. J.: The seasonally-varying influence of ENSO on rainfall and tropical cyclone activity in the Philippines,
Clim. Dynam., 32, 125-141, https://doi.org/10.1007/s00382008-0380-z, 2009.

Ma, L. J. C.: Urban Transformation in China, 1949-2000: A Review and Research Agenda, Environ. Plann. A, 34, 1545-1569, https://doi.org/10.1068/a34192, 2002.

Magaña, V., Amador, J. A., and Medina, S.: The Midsummer Drought over Mexico and Central America, J. Climate, 12, 1577-1588, https://doi.org/10.1175/15200442(1999)012<1577:TMDOMA>2.0.CO;2, 1999.

Moreiras, S. M.: Climatic effect of ENSO associated with landslide occurrence in the Central Andes, Mendoza Province, Argentina, Landslides, 2, 53-59, https://doi.org/10.1007/s10346-005-00464, 2005

Murshed, M. M.: Cutting of hills and human tragedy: An example of law enforcement loophole in the southeastern region of Bangladesh, International Journal of Geomatics and Geosciences, 4, 410 available at: http://www.ipublishing.co.in/ jggsarticles/volfour/EIJGGS4035.pdf (last access: 11 July 2018), 2013.

Naylor, R. L., Battisti, D. S., Vimont, D. J., Falcon, W. P., and Burke, M. B.: Assessing risks of climate variability and climate change for Indonesian rice agriculture, P. Natl. Acad. Sci. USA, 104, 7752-7757, https://doi.org/10.1073/pnas.0701825104, 2007.

NOAA: Tropical Cyclone Climatology, National Oceanic and Atmospheric Administration National Hurricane Center, available at: https://www.nhc.noaa.gov/climo/, last access: 20 February 2018a.

NOAA: Cold and Warm episodes by season, Historical El Nino/La Nina episodes (1950-present), National Oceanic and Atmospheric Administration National Hurricane Center, available at: http://origin.cpc.ncep.noaa.gov/products/analysis_ monitoring/ensostuff/ONI_v5.php, last access: 20 February 2018b.

NOAA: Historical Hurricane Tracks, available at: https://coast. noaa.gov/hurricanes/, last access: 20 February 2018c.

Open Street Map: https://www.openstreetmap.org/, last access: 8 June 2018.

Oven, K. J., Petley, D. N., Rigg, J. R., Dunn, C. E., and Rosser, N. J.: Landscape, livelihoods and risk: A study of community vulnerability to landslide events in Central Nepal, in: Climate change and disaster risk reduction, edited by: Aryal, K. R. and Gadema, Z., Disaster and Development Centre, School of Applied Science, Northumbria University, 94-102, 2008.

Planet Team: Planet Application Program Interface: In Space for Life on Earth. San Francisco, CA, available at: https://api.planet. com, last access: 11 November 2017.

Petley, D.: Global patterns of loss of life from landslides, Geology, 40, 927-930, https://doi.org/10.1130/G33217.1, 2012.

Petley, D. N.: On the impact of urban landslides, Geological Society, London, Eng. Geol. Sp., 22, 83-99, https://doi.org/10.1144/EGSP22.6, 2009.

Petley, D. N.: On the impact of climate change and population growth on the occurrence of fatal landslides in South, East and SE Asia, Q. J. Eng. Geol. Hydroge., 43, 487-496, https://doi.org/10.1144/1470-9236/09-001, 2010.

Petley, D. N., Dunning, S. A., and Rosser, N. J.: The analysis of global landslide risk through the creation of a database of worldwide landslide fatalities, in: Landslide Risk Management, edited 
by: Hungr, O., Fell, R., Couture, R., and Eberhardt, E., Taylor and Francis, London, UK, 367-373, 2005.

Petley, D. N., Hearn, G. J., Hart, A., Rosser, N. J., Dunning, S. A., Oven, K., and Mitchell, W. A.: Trends in landslide occurrence in Nepal, Nat. Hazards, 43, 23-44, https://doi.org/10.1007/s11069006-9100-3, 2007.

Rao, V. B. and Hada, K.: Characteristics of rainfall over Brazil: Annual variations and connections with the Southern Oscillation, Theor. Appl. Climatol., 42, 81-91, https://doi.org/10.1007/BF00868215, 1990.

Sati, S. P., Sundriyal, Y. P., and Rana, N.: Recent landslides in Uttarakhand: nature's fury or human folly, Curr. Sci., 100, 16171620, 2011.

Schneider, A. and Woodcock, C. E.: Compact, Dispersed, Fragmented, Extensive? A Comparison of Urban Growth in Twentyfive Global Cities using Remotely Sensed Data, Pattern Metrics and Census Information, Urban Stud., 45, 659-692, https://doi.org/10.1177/0042098007087340, 2008.

Sepúlveda, S. A. and Petley, D. N.: Regional trends and controlling factors of fatal landslides in Latin America and the Caribbean, Nat. Hazards Earth Syst. Sci., 15, 1821-1833, https://doi.org/10.5194/nhess-15-1821-2015, 2015.

Seneviratne, S. I., Nicholls, N., Easterling, D., Goodess, C. M., Kanae, S., Kossin, J., Luo, Y., Marengo, J., McInnes, K., Rahimi, M., Reichstein, M., Sorteberg, A., Vera, C., and Zhang, X.: Changes in climate extremes and their impacts on the natural physical environment, in: Managing the Risks of Extreme Events and Disasters to Advance Climate Change Adaptation, edited by: Field, C. B., Barros, V., Stocker, T. F., Qin, D., Dokken, D. J., Ebi, K. L., Mastrandrea, M. D., Mach, K. J., Plattner, G.-K., Allen, S. K., Tignor, M., and Midgley, P. M., A Special Report of Working Groups I and II of the Intergovernmental Panel on Climate Change (IPCC), Cambridge University Press, Cambridge, UK, and New York, NY, USA, 109-230, 2012.

Sierra, J. P., Arias, P. A., and Vieira, S. C.: Precipitation over Northern South America and Its Seasonal Variability as Simulated by the CMIP5 Models, Adv. Meteorol., 2015, 634720, https://doi.org/10.1155/2015/634720, 2015.

Singh, R., Umrao, R. K., and Singh, T. N.: Stability evaluation of road-cut slopes in the Lesser Himalaya of Uttarakhand, India: conventional and numerical approaches, B. Eng. Geol. Environ., 73, 845-857, https://doi.org/10.1007/s10064-013-0532-1, 2014.

Soldati, M., Corsini, A., and Pasuto, A.: Landslides and climate change in the Italian Dolomites since the Late glacial, Catena, 55, 141-161, https://doi.org/10.1016/S0341-8162(03)00113-9, 2004.

Smyth, C. G. and Royle, S. A.: Urban landslide hazards: incidence and causative factors in Niterói, Rio de Janeiro State, Brazil, Appl. Geogr., 20, 95-118, https://doi.org/10.1016/S01436228(00)00004-7, 2000.

Srivastava, A., Goyal, C. R., and Jain, A.: Review of Causes of foundation failures and their possible preventive and remedial measures, in: Proceedings of 4th KKU- International Engineering Conference (KKU-IENC2012), Khon Kaen, Thailand, 10-12 May 2012.

Stanley, T. and Kirschbaum, D. B.: A heuristic approach to global landslide susceptibility mapping, Nat. Hazards, 87, 145-164, https://doi.org/10.1007/s11069-017-2757-y, 2017.
Taylor, F. E., Malamud, B. D., Freeborough, K., and Demeritt, D.: Enriching Great Britain's National Landslide Database by searching newspaper archives, Geomorphology, 249, 52-68, https://doi.org/10.1016/j.geomorph.2015.05.019, 2015.

Tedeschi, R. G., Cavalcanti, I. F. A., and Grimm, A. M.: Influences of two types of ENSO on South American precipitation, Int. J. Climatol., 33, 1382-1400, https://doi.org/10.1002/joc.3519, 2013.

The Economist: Rubies in the sky with diamonds, available at: http: //www.economist.com/node/21528623 (last access: 20 February 2018), 2011.

Trenberth, K. E. and Shea, D. J.: Atlantic hurricanes and natural variability in 2005, Geophys. Res. Lett., 33, L12704, https://doi.org/10.1029/2006GL026894, 2006.

Tschoegl, L., Below, R., and Guha-Sapir, D.: An analytical review of selected data sets on natural disasters and impacts, Centre for Research on the Epidemiology of Disasters, UNDP/CRED Workshop on Improving Compilation of Reliable Data on Disaster Occurrence and Impact, Bangkok, Thailand, 21 pp., 2006.

Turner, A. G. and Annamalai, H.: Climate change and the South Asian summer monsoon, Nat. Clim. Chang., 2, 587-595, https://doi.org/10.1038/nclimate1495, 2012.

UNESCO: Annual summary of information on natural disasters, no. 6: 1971, United Nations Educational, Scientific and Cultural Organization, Paris, France, 82 pp., 1973.

United Nations Statistics Division (UNSD): Standard country or area codes for statistical use, available at: http://unstats.un. org/unsd/methods/m49/m49.htm (last access: 10 August 2016), 2018.

Valdiya, K. S.: Catastrophic Landslides in Uttaranchal, Central Himalaya, J. Geol. Soc. India, 52, 483-486, 1998.

Van Den Eeckhaut, M. and Hervás, J.: State of the art of national landslide databases in Europe and their potential for assessing landslide susceptibility, hazard and risk, Geomorphology, 139140, 545-558, https://doi.org/10.1016/j.geomorph.2011.12.006, 2012.

van Westen, C. J., Castellanos, E., and Kuriakose, S. L.: Spatial data for landslide susceptibility, hazard, and vulnerability assessment: An overview, Eng. Geol., 102, 112-131, https://doi.org/10.1016/j.enggeo.2008.03.010, 2008.

Varnes, D. J. and IAEG Commission on Landslides: Landslide hazard zonation: a review of principles and practice: Paris, UNESCO, Paris, France, 63 pp., 1984.

Webster, P. J., Magaña, V. O., Palmer, T. N., Shukla, J., Tomas, R. A., Yanai, M., and Yasunari, T.: Monsoons: Processes, predictability, and the prospects for prediction, J. Geophys. Res., 103, 14451-14510, https://doi.org/10.1029/97JC02719, 1998.

World Bank: The World Bank data, available at: https://data. worldbank.org/indicator/, last access: 19 February 2018a.

World Bank: Transport: At a Glance, The World Bank, available at: http://www.worldbank.org/en/topic/transport/overview, last access: 22 February 2018 b.

Wu, X., Chen, X., Benjamin Zhan, F., and Hong, S.: Global research trends in landslides during 1991-2014: a bibliometric analysis, Landslides, 12, 1215-1226, https://doi.org/10.1007/s10346-0150624-z, 2015.

Xie, P., Janowiak, J. E., Arkin, P. A., Adler, R., Gruber, A., Ferraro, R., Huffman, G. J., and Curtis, S.: GPCP Pentad Precipitation Analyses: An Experimental Dataset Based on Gauge Ob- 
servations and Satellite Estimates, J. Climate, 16, 2197-2214, https://doi.org/10.1175/2769.1, 2003.

Yang, H., Xia, J., Thompson, J. R., and Flower, R. J.: Urban construction and demolition waste and landfill failure in Shenzhen, China, Waste Manage., 63, 393-396, https://doi.org/10.1016/j.wasman.2017.01.026, 2017.

Yang, F. and Lau, K.-M.: Trend and variability of China precipitation in spring and summer: linkage to seasurface temperatures, Int. J. Climatol., 24, 1625-1644, https://doi.org/10.1002/joc.1094, 2004.

Yu, K., Wang, S., and Li, D.: The negative approach to urban growth planning of Beijing, China, J. Environ. Plann. Man., 54, 12091236, https://doi.org/10.1080/09640568.2011.564488, 2011.
Zhang, F., Liu, G., Chen, W., Liang, S., Chen, R., and Han, W.: Human-induced landslide on a high cut slope: a case of repeated failures due to multi-excavation, Journal of Rock Mechanics and Geotechnical Engineering, 4, 367-374, https://doi.org/10.3724/SP.J.1235.2012.00367, 2012.

Zhou, T., Wu, B., and Dong, L.: Advances in research of ENSO changes and the associated impacts on AsianPacific climate, Asia-Pacific J. Atmos. Sci., 50, 405-422, https://doi.org/10.1007/s13143-014-0043-4, 2014.

Zou, F., Zhan, Q., and Zhang, W.: Quantifying the impact of human activities on geological hazards in mountainous areas: evidence from Shennongjia, China, Nat. Hazards, 90, 137-155, https://doi.org/10.1007/s11069-017-3039-4, 2018. 